\title{
Article \\ Human MAIT Cells Respond to Staphylococcus aureus with Enhanced Anti-Bacterial Activity
}

\author{
Andrew J. R. Cooper ${ }^{1}$, Jonah Clegg ${ }^{1}$, Féaron C. Cassidy ${ }^{2}$, Andrew E. Hogan ${ }^{2} \mathbb{D}$ and Rachel M. McLoughlin ${ }^{1, *}$ \\ 1 Host Pathogen Interactions Group, School of Biochemistry and Immunology, Trinity Biomedical Sciences \\ Institute, Trinity College Dublin, D02 PN40 Dublin, Ireland; cooperan@tcd.ie (A.J.R.C.); \\ jonah.x.clegg@gsk.com (J.C.) \\ 2 Kathleen Lonsdale Institute for Human Health Research, Maynooth University, W23 F2K8 Maynooth, Ireland; \\ Fearon.Cassidy@mu.ie (F.C.C.); Andrew.E.Hogan@mu.ie (A.E.H.) \\ * Correspondence: rachel.mcloughlin@tcd.ie; Tel.: +353-1-896-2526
}

Citation: Cooper, A.J.R.; Clegg, J.; Cassidy, F.C.; Hogan, A.E.; McLoughlin, R.M. Human MAIT Cells Respond to Staphylococcus aureus with Enhanced Anti-Bacterial Activity. Microorganisms 2022, 10, 148. https://doi.org/10.3390/ microorganisms10010148

Academic Editor: Moriya Tsuji

Received: 30 November 2021

Accepted: 5 January 2022

Published: 12 January 2022

Publisher's Note: MDPI stays neutral with regard to jurisdictional claims in published maps and institutional affiliations.

Copyright: (C) 2022 by the authors. Licensee MDPI, Basel, Switzerland. This article is an open access article distributed under the terms and conditions of the Creative Commons Attribution (CC BY) license (https:// creativecommons.org/licenses/by/ $4.0 /)$.

\begin{abstract}
Mucosal-Associated Invariant T (MAIT) cells have been shown to play protective roles during infection with diverse pathogens through their propensity for rapid innate-like cytokine production and cytotoxicity. Among the potential applications for MAIT cells is to defend against Staphylococcus aureus, a pathogen of serious clinical significance. However, it is unknown how MAIT cell responses to $S$. aureus are elicited, nor has it been investigated whether MAIT cell cytotoxicity is mobilized against intracellular S. aureus. In this study, we investigate the capacity of human MAIT cells to respond directly to $S$. aureus. MAIT cells co-cultured with dendritic cells (DCs) infected with S. aureus rapidly upregulate CD69, express IFN $\gamma$ and Granzyme B and degranulate. DC secretion of IL-12, but not IL-18, was implicated in this immune response, while TCR binding of MR1 is required to commence cytokine production. MAIT cell cytotoxicity resulted in apoptosis of S. aureus-infected cells, and reduced intracellular persistence of $S$. aureus. These findings implicate these unconventional $\mathrm{T}$ cells in important, rapid anti-S. aureus responses that may be of great relevance to the ongoing development of novel anti-S. aureus treatments.
\end{abstract}

Keywords: Staphylococcus aureus; MAIT cell; vaccines; cell mediated immunity; IFN $\gamma$; dendritic cell

\section{Introduction}

Staphylococcus aureus is a major cause of infection in diverse tissue settings, including the bloodstream where it is one of the most common and, unfortunately, most lethal, with mortality ranging from 15 to 50\% [1-3]. These are striking statistics which are likely to be further exacerbated, given the rising problem of antibiotic-resistant strains [4]. There is an urgent need for new strategies to prevent and treat $S$. aureus infection. Despite significant efforts, an efficacious $S$. aureus vaccine remains elusive [5]. Multiple candidate vaccines have succeeded in inducing protective immunity in the mouse, but without successful translation to human subjects [6-10], highlighting the disparities that exist between murine and human immunity that are directly impeding progress within the field. It is worth noting that to date no candidate vaccine in late-stage efficacy trials has successfully mobilised enduring human $T$ cell responses against $S$. aureus $[11,12]$. IFN $\gamma$ and IL-17, key cytokines produced by $\mathrm{T}$ cells, are now known to be indispensable in anti-staphylococcal immunity. $\mathrm{HIV}$, diabetes mellitus and end-stage renal disease, conditions that limit IFN $\gamma$ production, are associated with heightened susceptibility to $S$. aureus bacteraemia $[13,14]$, while HyperIgE syndrome, which leads to IL-17 deficiency, is associated with susceptibility to $S$. aureus mucosal infections $[15,16]$. While these patients typically have a number of risk factors that may predispose them to susceptibility, these correlations have inspired significant interest in how individual $\mathrm{T}$ cell subsets contribute to the protective immune response to $S$. aureus. $\mathrm{T}_{\mathrm{h}} 1$ and $T_{h} 17$ classes of helper $T$ cells play important roles in activation of macrophages $[17,18]$, neutrophil survival [19], and mediating the efficient killing of intracellular S. aureus by 
infected cells [20]. Naturally then, T cells are now considered important correlates of immunity for targeting in next-generation vaccines [21]. More recently a potential role for unconventional T cells, in particular $\gamma \delta \mathrm{T}$ cells, in S. aureus defence has emerged [22-25]. Importantly, $\gamma \delta \mathrm{T}$ cells have shown some hallmarks of pathogen-specific expansion and memory $[26,27]$, suggesting the tantalizing possibility that these cells could be vaccine targetable [9].

One T cell population that has being largely overlooked in the quest to identify correlates of S. aureus immunity are the Mucosal-Associated Invariant T (MAIT) cells. A possible reason for their neglect may be their infrequency in murine tissues $[28,29]$, but they contribute $1-10 \%$ of the T cells within human blood and are further enriched in barrier tissues $[28,30]$. MAIT cells are activated both by innate cytokines and by binding of the unique, conserved MAIT cell TCR to the MHC-like molecule MR1 in complex with the metabolites 5-OP-RU and 5-OE-RU, which are produced by a wide variety of bacteria but not human cells [31,32]. Once activated, MAIT cells are robust secretors of IFN $\gamma$ and cytotoxic mediators in acute infection scenarios [33]. In mice, in spite of their low frequency, MAIT cells have been shown to play important non-redundant roles in protection against multiple pathogens. MR1-deficient mice (which lack MAIT cells) are susceptible to Klebsiella pneumoniae [34], Mycobacterium bovis [35], Mycobacterium abscessus [36], Legionella longbeachae [37], and polymicrobial sepsis [38]. In these studies, the absence of MAIT cells resulted in failure to control infection and in heightened mortality. Accumulating evidence also supports an important role for MAIT cells in human infection settings. Patients suffering from pulmonary infections like tuberculosis have lower circulating MAIT cell frequencies [36,39,40], and the distribution of Mycobacterium-reactive MAIT cells in TB-afflicted individuals suggests that peripheral MAIT cells traffic to the site of infection during active infection [36,39]. Severe cases of COVID-19 also correlate with reduced frequencies of circulating MAIT cells [40]. To date however there is relatively little understanding of how circulating MAIT cells contribute to immune defence within the bloodstream. Sepsis has been shown to be associated with a decrease in circulating MAIT cells [41], while MAIT cells from acute sepsis patients (at Day 1 post-admission) show notably modified phenotypic profiles compared to both MAIT cells from healthy donors, and MAIT cells from the same patients at Day 90 post-admission, suggesting acute MAIT cell responses which revert to the status quo ante following infection resolution; this includes significantly elevated expression of CD69 and reduced capacity for IFN $\gamma$ production in response to Escherichia coli infection in vitro [38]. This study did not however distinguish data for specific causes of sepsis.

A role for MAIT cells in S. aureus bloodstream infection, protective or otherwise, has not yet been established. Notably, some specific MAIT cell clones can produce IFN $\gamma$ in co-culture with S. aureus-infected cells [39], and when PBMCs are exposed to staphylococcal superantigens, MAIT cells are 'hyperactivated', resulting in strong IFN $\gamma$ and TNF production, and eventual anergy; while a small part of this activation is accounted for by direct superantigen binding of the TCR, neutralisation of the innate cytokine IL-18 abolished the vast majority of cytokine production, demonstrating that MAIT cell responses to superantigens are largely cytokine-mediated and are secondary to the activation of other cells [42,43]. In addition to being robust secretors of IFN $\gamma$ [33], a potentially important correlate of protection against $S$. aureus bloodstream infection in humans [18,44], MAIT cells are also strong secretors of cytotoxic mediators and play a role in the elimination of intracellular parasites [33]. Given S. aureus's ability to survive intracellularly and even to disseminate inside circulating leukocytes [45-47], we might expect that cytotoxic responses to $S$. aureus-infected cells would be beneficial for combating S. aureus infection. However, the effects of MAIT cell cytotoxicity on S. aureus are completely untested. Additionally, no study has yet clarified the mechanism of activation of MAIT cells by S. aureus-infected cells, whether through MR1 presentation of riboflavin intermediates or through cytokines.

Here, we investigated the ability of human blood-derived MAIT cells to respond to S. aureus. MAIT cells responded to S. aureus-infected DCs with IFN $\gamma$ and Granzyme B 
production. Both IL-12 and MR1 engagement of the MAIT TCR were implicated in this interaction. MAIT cells displayed an enhanced cytotoxic phenotype, with clear degranulation, which resulted in the apoptosis of S. aureus-infected cells, and reduced persistence of S. aureus in cultures.

\section{Materials and Methods}

\subsection{Cell Culture}

PBMCs were isolated by density gradient centrifugation using Ficoll (Lymphoprep). Monocytes were isolated from PBMCs by magnetic separation using a CD14 MACS kit (Miltenyi Biotec, North Rhine-Westphalia, Germany) and then cultured for propagation of DCs by incubation for 6 days in complete RPMI (RPMI 1640 (Sigma-Aldrich, Arklow, Ireland) with 10\% heat-inactivated FBS (Sigma-Aldrich), $2 \mathrm{mM}$ L-glutamine (Sigma-Aldrich), $100 \mathrm{U} / \mathrm{mL}$ penicillin (Sigma-Aldrich) and $100 \mu \mathrm{g} / \mathrm{mL}$ streptomycin (Sigma-Aldrich)) supplemented with $100 \mathrm{ng} / \mathrm{mL}$ GM-CSF (PeproTech, London, UK). On day 3, cells were supplemented with fresh complete RPMI formulated as above with an additional $50 \mathrm{ng} / \mathrm{mL}$ IL-4 (PeproTech). On day 6, monocyte-derived DCs were collected and resuspended in antibiotic-free media for infection. Cell purity was verified by flow cytometry by staining with CD11b and DC-SIGN and was routinely $>95 \%$.

MAIT cells were expanded in vitro as previously described [48]. Healthy donor PBMCs were cultured for 10-14 days in complete RPMI supplemented with $1 \mu \mathrm{g} / \mathrm{mL}$ 5-A-RU and $100 \mu \mathrm{M}$ methylglyoxal, at a concentration of $1 \times 10^{6} \mathrm{PBMCs} / \mathrm{mL}$. On day $1200 \mu \mathrm{L}$ of media from each well was discarded and replaced with $200 \mu \mathrm{L}$ of fresh media containing IL-2 (6.75 ng/mL final concentration in culture). Following this, IL-2 was added by replacing $1 \mathrm{~mL}$ media (IL-2 concentration $33.3 \mathrm{ng} / \mathrm{mL}$ ) every 3 days, and cells were monitored microscopically and split as needed. At day 10-14, cells were MACS-purified using APC-conjugated Abs against the MAIT cell TCR and an anti-APC MACS kit (Miltenyi Biotec), and tested for purity using fluorescently conjugated MR1 tetramers procured from the NIH tetramer facility. Purity was routinely $>95 \%$.

THP-1 cells were derived from maintained cell lines, obtained from the ECACC [49], cultured in complete RPMI and subcultured at $3 \times 10^{5}$ cells $/ \mathrm{mL}$, approximately every 3 days.

\subsection{Bacteria}

S. aureus strains PS80 [50], USA300 LAC::lux [51] and Newman [52], and E. coli strain EC958 [53] have been described previously. S aureus strains were cultured overnight on Columbia agar supplemented with $2 \% \mathrm{NaCl}$ (PS80), or on tryptic soy agar (USA300 and Newman); E. coli was grown overnight on tryptic soy agar supplemented with $4 \%$ defibrinated sheep's blood (ThermoFisher Scientific, Gloucester, UK). Bacteria were suspended in PBS, enumerated by optical spectrometry and diluted to $1 \times 10^{8} \mathrm{CFU} / \mathrm{mL}$. CFU counts were verified by plating on appropriate agar overnight.

\subsection{In Vitro Infection Assay}

DCs were resuspended in antibiotic-free complete RPMI. Then, $1 \times 10^{5}$ cells were transferred to each well of 96-well flat-bottom cell culture plates (Corning). DCs were inoculated with $1 \times 10^{6} \mathrm{CFU}$ of bacteria per well and incubated for $3 \mathrm{~h}$ before centrifugation and media replacement with complete RPMI supplemented with gentamicin $(200 \mu \mathrm{g} / \mathrm{mL}$; Sigma-Aldrich) to eliminate live extracellular bacteria. At this point, $1 \times 10^{5}$ expanded MAIT cells were added to each well for the indicated lengths of time. For most assays (unless otherwise indicated), up to four sets of MAIT cells isolated from four independent donors were paired with each individual heterologous DC donor.

For specific experiments, neutralizing Abs for IL-12 p40 (clone C8.6, $20 \mu \mathrm{g} / \mathrm{mL}$; Biolegend, San Diego, CA, USA), IL-18 (clone 914205, $20 \mu \mathrm{g} / \mathrm{mL}$; R\&D), or MR1 (clone 26.5, $10 \mu \mathrm{g} / \mathrm{mL}$; Biolegend), or their isotype controls (IgG1 $\mathrm{\kappa}$ and IgG2aк; Biolegend; $10-20 \mu \mathrm{g} / \mathrm{mL}$ ), were added to co-cultures, either alongside MAIT cells or, in the case 
of anti-MR1 antibodies, 30 min prior to addition of MAIT cells. For blocking of TCR activity, the small molecule inhibitor of tyrosine kinases Dasatinib [54] was added along with MAIT cells $(100 \mathrm{nM})$ for the duration of culturing. For cell-cell contact-blocking experiments, DCs were cultured and infected in the lower chamber of a 96-well 0.4-mm transmembrane culture system (Millipore-Sigma, Arklow, Ireland) before gentamicin treatment as described, at which point MAIT cells were placed in the upper chamber.

For direct exposure of MAIT cells to bacteria, MAIT cells were resuspended in antibiotic-free complete RPMI and $1 \times 10^{5}$ cells transferred to each well of 96-well flatbottom cell culture plates (Corning, Flintshire, UK) before inoculation with $1 \times 10^{6} \mathrm{CFU}$ of bacteria per well. Cells were then incubated for $3 \mathrm{~h}$ before centrifugation, and media was replaced with complete RPMI supplemented with gentamicin $(200 \mu \mathrm{g} / \mathrm{mL}$; Sigma-Aldrich) to eliminate live extracellular bacteria.

THP- 1 cells $\left(1 \times 10^{5}\right.$ cells per well $)$ were cultured in 96-well flat-bottom cell culture plates and infected with $1 \times 10^{5} \mathrm{CFU}$ of bacteria per well for $3 \mathrm{~h}$ before similar gentamicin treatment and addition of $1 \times 10^{5}$ MAIT cells. At $24 \mathrm{~h}$, THP- 1 cells were collected to assess viability, using Annexin V/PI staining, and intracellular bacterial burdens.

In all experiments, supernatants were collected at specific timepoints for analysis of cytokine production by ELISA, and in some instances, cells were resuspended in media supplemented with brefeldin A (BFA) $(10 \mu \mathrm{g} / \mathrm{mL}$; Sigma-Aldrich) for the final $4 \mathrm{~h}$ of culture, after which cells were collected and stained for flow cytometry.

For CFU enumeration from infected cells, cultures were washed twice by centrifugation in sterile PBS before lysis for $10 \mathrm{~min}$ in $0.1 \%$ Triton X-100. Lysates were plated on TSA overnight before $\mathrm{CFU}$ enumeration.

\subsection{Flow Cytometry}

Following BFA treatment for the final $4 \mathrm{~h}$, cells were resuspended in 1:1000 dilution of Fixable Viability Stain (Life Technologies, Gloucester, UK) for LIVE/DEAD cell determination. Cells were subsequently resuspended in PBS with 1\% BSA (Sigma-Aldrich) and treated with Fc $\gamma$ block (Life Technologies). For extracellular cell staining, cells were labelled with fluorochrome-conjugated Abs against CD3 (clone OKT3; Life Technologies), CD69 (clone FN50; BD Biosciences, Wokingham, UK), CD86 (clone IT2.2; Biolegend), DC-SIGN (clone eB-h209; Life Technologies) and CD107a (clone H4A3; Biolegend). Cells were then fixed and permeabilized using the FIX and PERM Kit (Life Technologies) before intracellular staining with fluorochrome-conjugated Abs against IFN $\gamma$ (clone 4S.B3; Biolegend), IL-17A (clone eBIO64 DEC17; Life Technologies), Granzyme B (clone GB11; Biolegend), perforin (clone B-D48; Biolegend), granulysin (clone DH2; Biolegend), and granzyme A (clone CB9; Biolegend). For apoptosis analysis, cells were stained with Abs against Annexin $\mathrm{V}$ (Biolegend) and with propidium iodide (PI) (Biolegend) before immediate acquisition. Flow cytometric data were acquired with a BD LSRFortessa (BD Biosciences) and analysed using FlowJo v10.6.2 (Treestar, Ashland, OR, USA). Fluorescence minus one controls were used for the setting of gates.

\subsection{ELISA}

Sandwich ELISAs were performed on culture supernatants as per the manufacturer's instructions for IFN $\gamma$, IL-12, IL-17A, TNF, Granzyme B (Biolegend) and IL-18 (Life Technologies).

\subsection{Statistical Analysis}

Statistical analysis was performed with SPSS Statistics 24 (IBM, New York, NY, USA) software. Friedman two-way ANOVA on groups was followed by pairwise Wilcoxon signed-rank post-tests. For direct comparisons of DC single cultures to cocultures in which DCs were generated from single donors and cocultured with MAIT cells from up to four separate donors, or comparisons of THP-1 cell single co-cultures to cocultures with MAIT cells from multiple donors, forward fill imputation was used to correctly match 
each DC or THP- 1 value to each paired coculture value. In all situations, $p \leq 0.05$ was considered significant.

\section{Results}

3.1. Human Blood-Derived MAIT Cells Are Activated in Co-Culture with S. aureus-Infected DCs

To establish if blood-derived MAIT cells could respond directly to S. aureus, MAIT cells were expanded in vitro from PBMCs. MR1 tetramer-positive cells were confirmed to be predominantly $\mathrm{CD} 8^{+} \mathrm{CD} 4^{-}$, with a smaller population of $\mathrm{CD} 8^{-} \mathrm{CD} 4^{-}$cells and even fewer $\mathrm{CD}^{+}$cells (Figure S1A); these frequencies match those typically seen in MAIT cells isolated from the bloodstream [55], confirming that the process of in vitro expansion does not alter this population breakdown. All cells were $\mathrm{CD} 161^{+}$, and a majority were CD161 ${ }^{\text {hi }}$ (Figure S1C), suggestive of a largely mature cell population, again redolent of circulating MAIT cells [55].

DCs were infected with a panel of $S$. aureus isolates, in addition to the gram negative bacterium E. coli, a known activator of human MAIT cells [36]. Following $3 \mathrm{~h}$ infection, extracellular bacteria were eliminated from all cultures by gentamicin treatment, and MAIT cells were added for a further $24 \mathrm{~h}$, after which cell culture supernatants were collected and cytokine secretion analysed by ELISA. Additionally, MAIT cells were directly exposed to live bacteria for $3 \mathrm{~h}$, followed by gentamicin treatment, and supernatants collected $24 \mathrm{~h}$ post bacterial exposure. All cells were treated with Brefeldin A (BFA) for the final $4 \mathrm{~h}$ of culture, and subsequently cell populations analysed by flow cytometry.

Direct exposure of MAIT cells to $S$. aureus did not result in expression of Granzyme B or IFN $\gamma$ (Figure 1). By contrast, at $24 \mathrm{~h}$ MAIT cells had significantly upregulated CD69 (Figure 1A) and were producing high levels of both Granzyme B (Figure 1C) and IFN $\gamma$ (Figure $1 \mathrm{E}, \mathrm{G}$ ) following co-culture with DCs infected with all S. aureus strains. Cytokine levels were comparable to those induced by E. coli-infected DCs. IL-17A was undetectable in all culture conditions tested, while TNF production in response to $S$. aureus-infected DCs was substantial in the co-cultures (Figure S2). MAIT cells also demonstrated significantly elevated expression of the degranulation marker CD107a (Figure 1H) and secretion of Granzyme B into culture media (Figure 1I) following co-culture with S. aureus or E.coliinfected DCs, suggesting a rapid adoption of a cytotoxic phenotype alongside the IFN $\gamma$ response. In spite of high Granzyme expression, DC viability was not reduced in the co-cultures at $24 \mathrm{~h}$ (Figure S3).

\subsection{Activation of MAIT Cells by S. aureus-Infected DCs Is Enhanced by DC Production of IL-12}

IL-12 is a key mediator of T cell activation, including MAIT cells, particularly for the secretion of IFN $\gamma$ and cytotoxic mediators [56-58]. To establish the role of IL-12 in activating MAIT cells in response to $S$. aureus infection, DCs were infected with selected strains of S. aureus or E. coli for $3 \mathrm{~h}$ and, following elimination of bacteria by gentamicin treatment, resuspended in media supplemented with IL-12-neutralising Abs, and co-cultured with MAIT cells for $24 \mathrm{~h}$. CD69 expression by MAIT cells was unaffected by IL-12 neutralisation (Figure 2A), but Granzyme B (Figure 2B) and IFN $\gamma$ (Figure 2C) expression were significantly decreased when measured by flow cytometry. However, analysis of total culture supernatants revealed that actual levels of secreted IFN $\gamma$ were less affected by IL-12 neutralisation (Figure 2D). The results indicate that IL-12 plays a significant but not exclusive role in the activation of MAIT cells in response to $S$. aureus-infected DCs. IL-12 neutralisation had no effect on E. coli-induced activation of MAIT cells which is consistent with previously published work [59]. Significant levels of IL-12 are produced by DCs following exposure to S. aureus (Figure S4A), but IL-18 is absent in DC cultures (Figure S4B); so unsurprisingly, IL-18-neutralising Abs had no effect on MAIT cell activation in this assay (Figure S4C). 
DAIT cells only $\square$ MAIT-DC Co-culture

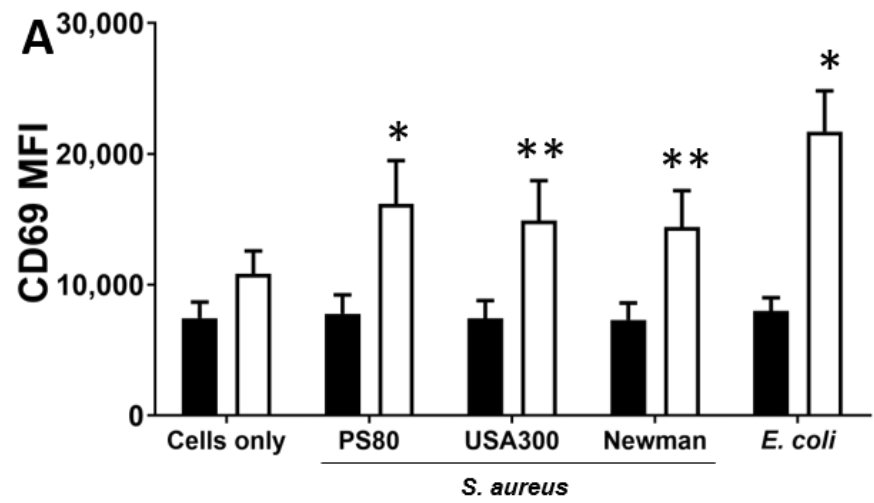

$\square$ Uninfected MAIT-DC Co-culture

$\square$ PS80-infected MAIT-DC Co-culture

C
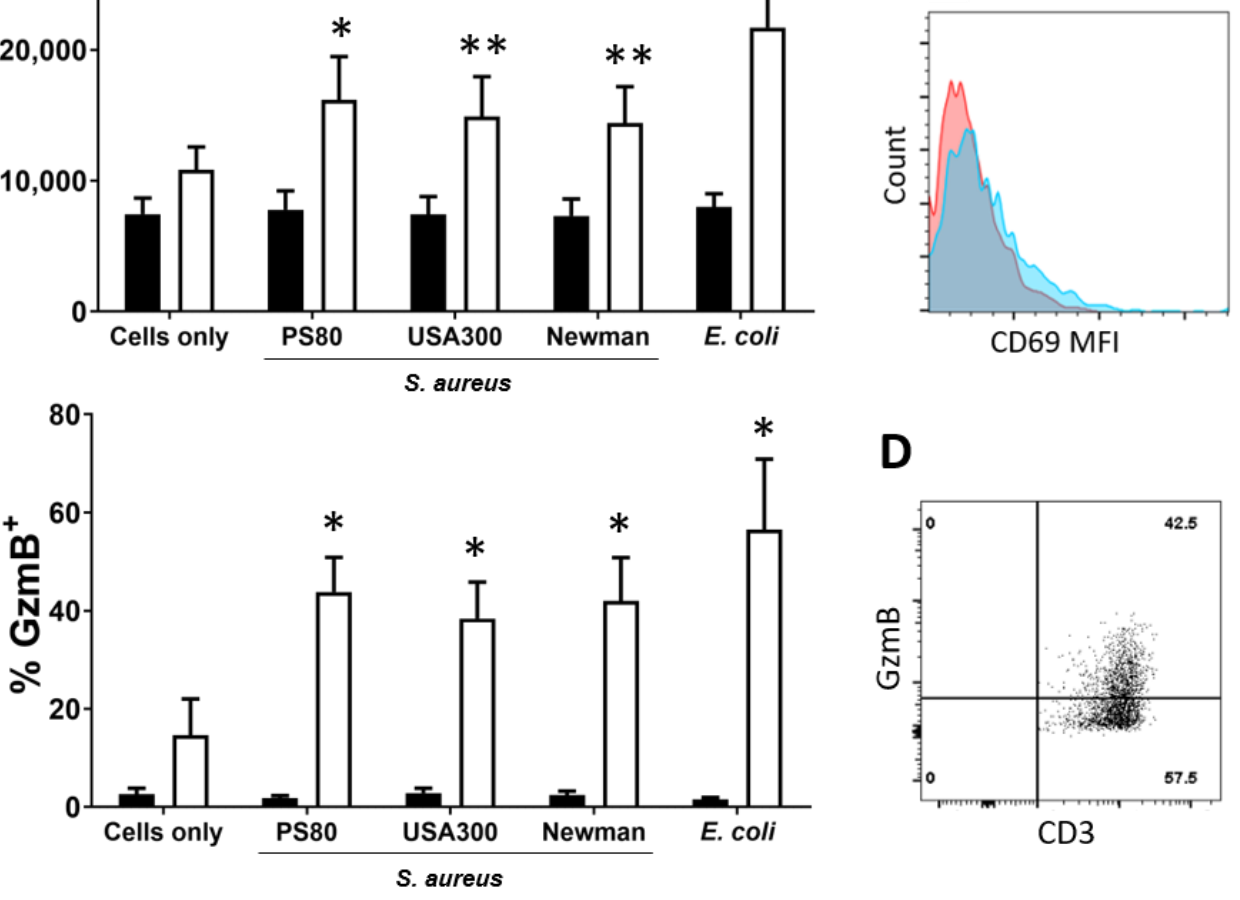

CD69 MFI

D

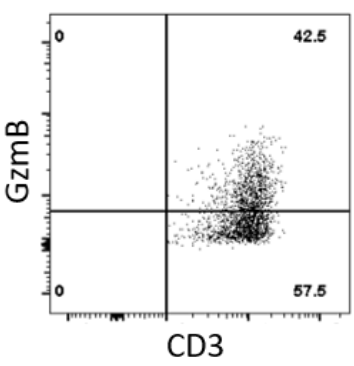

E

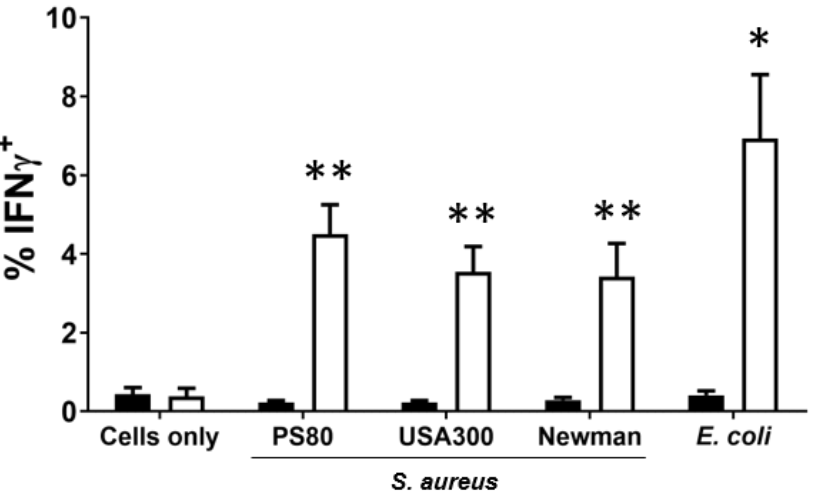

F
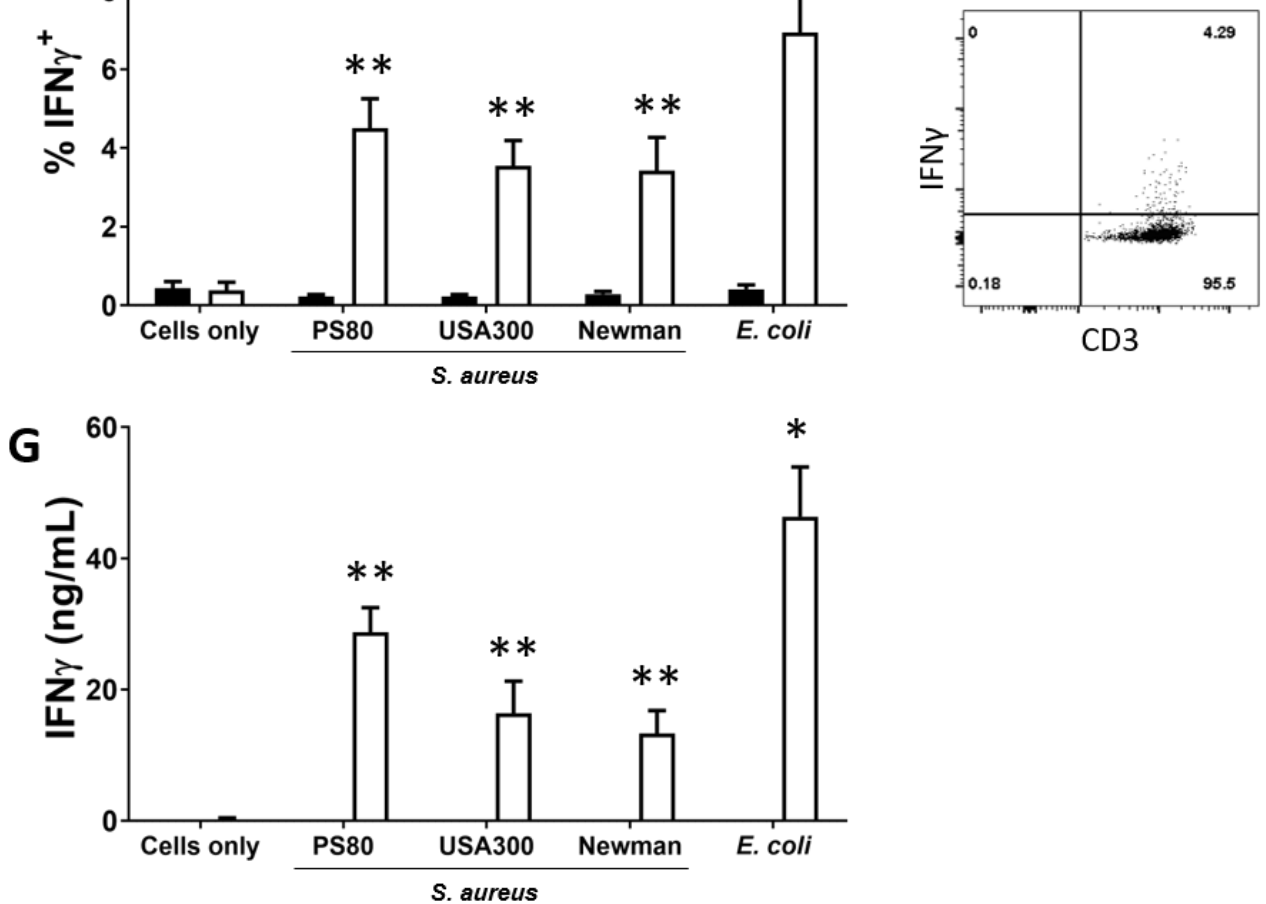

Figure 1. Cont. 
$\mathrm{H}$

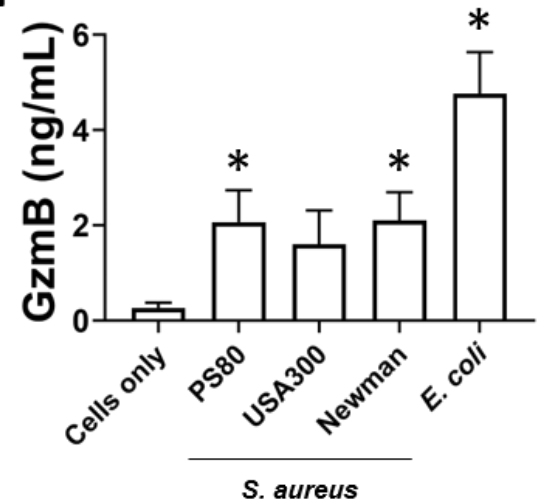

I

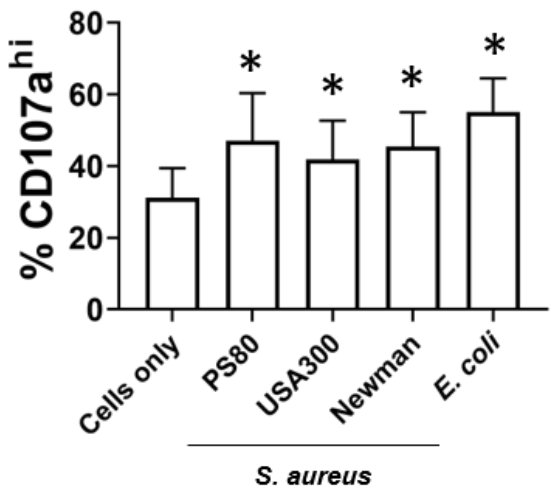

J

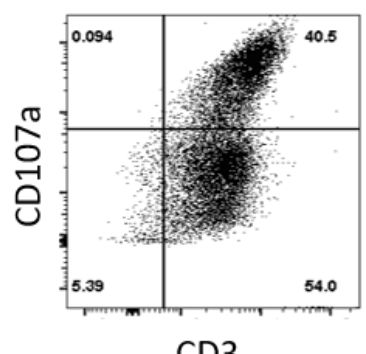

$\mathrm{CD} 3$

Figure 1. Human blood-derived Mucosal-Associated Invariant T (MAIT) cells are activated in coculture with S. aureus-infected DCs to express CD69, Granzyme B, IFN $\gamma$ and CD107a. MAIT cells and DCs $\left(5 \times 10^{5}\right.$ cells $\left./ \mathrm{mL}\right)$ were infected with $S$. aureus (strains PS80, USA300, Newman) and E. coli (strain EC958) at MOI 10 for $3 \mathrm{~h}$ before elimination of extracellular bacteria by gentamicin treatment. DCs were then co-cultured with uninfected MAIT cells $\left(5 \times 10^{5} / \mathrm{mL}\right)$ for $24 \mathrm{~h}$. Cells were treated with BFA for the final $4 \mathrm{~h}$ of culture. Expression of CD69 (A), Granzyme B ('GzmB') (C), IFN $\gamma(\mathbf{E})$ and CD107a (I) by MAIT cells were assessed by flow cytometry, and concentration of $\operatorname{IFN} \gamma(\mathbf{G})$ and Granzyme B $(\mathbf{H})$ in culture supernatants assessed by ELISA. Results are expressed as mean fluorescence intensity (MFI) of total live singlet $\mathrm{CD}^{+}$cells + SEM (A), mean \% positive cells within total live singlet $\mathrm{CD}^{+}$cells $+\mathrm{SEM}(\mathrm{C}, \mathrm{E}, \mathbf{I})$, or mean concentration in culture supernatants + $\operatorname{SEM}(\mathbf{G}, \mathbf{H})$. Representative FACS plots for PS80 infection are shown $(\mathbf{B}, \mathbf{D}, \mathbf{F}, \mathbf{J}) . n=4-10$ DC donors per group, $n=7-18$ MAIT cell donors per group. 'Cells only' refers to uninfected cultures. Statistical analysis by pairwise Wilcoxon signed rank test, with all columns compared directly to cells only. ${ }^{*} p \leq 0.05,{ }^{* *} p \leq 0.01$.

\subsection{Activation of MAIT Cells by S. aureus-Infected DCs Is Dependent on Cell-Cell Contact}

Alongside cytokine exchange, direct cell-cell contact also governs activation of conventional T cells by DCs. To determine the role of contact in the activation of MAIT cells during $S$. aureus infection, DCs were infected with selected strains of $S$. aureus or E. coli for $3 \mathrm{~h}$ and, following elimination of bacteria by gentamicin treatment, co-cultured with MAIT cells for $24 \mathrm{~h}$ in a multi-chamber system in which cell-cell contact was blocked by a $0.4 \mu \mathrm{m}$ membrane, without impeding exchange of secreted molecules. Activation of MAIT cells was significantly reduced as assessed by expression of CD69 (Figure 3A), Granzyme B (Figure 3B) and IFN $\gamma$ (Figure 3C,D). CD69, Granzyme B and IFN $\gamma$ levels were restored to those seen in MAIT cell-only cultures. These results indicate that, while MAIT cells have been shown elsewhere to respond to cytokines alone in an innate-like manner [58], they do not do so during $S$. aureus infection; instead, MAIT cell activation following $S$. aureus or E. coli infection is primarily dependent upon direct cell-cell contact.

To establish whether this contact was mediated via engagement of the TCR by the MHC-like molecule MR1 (shown previously to be a major route of MAIT cell activation [36]), we interrogated the TCR-MR1 axis by treatment of MAIT-DC co-cultures with blocking agents targeted against both molecules. First, to confirm the role of the TCR, co-cultures were treated with Dasatinib, a small molecule inhibitor of tyrosine kinases which has been found to specifically target TCR-related downstream signalling in T cells [54]. DCs were infected with selected strains of $S$. aureus or E. coli for $3 \mathrm{~h}$ and, following elimination of bacteria by gentamicin treatment, co-cultured with MAIT cells in the presence of Dasatinib. Expression of CD69, IFN $\gamma$ and Granzyme B in response to both S. aureus and E. coli were all significantly decreased by Dasatinib treatment (Figure 3E-H). Although Dasatinib had some effect on DC activation (Figure S5), the magnitude of this response was much less than the overall effect observed on MAIT cell activation, which was of a similar magnitude to that observed when cell-cell contact was blocked. 


\title{
$\square$ No Treatment
}

$20 \mu \mathrm{g} / \mathrm{mL}$ Isotype Control

\author{
$20 \mu \mathrm{g} / \mathrm{mL}$ Anti-IL-12
}
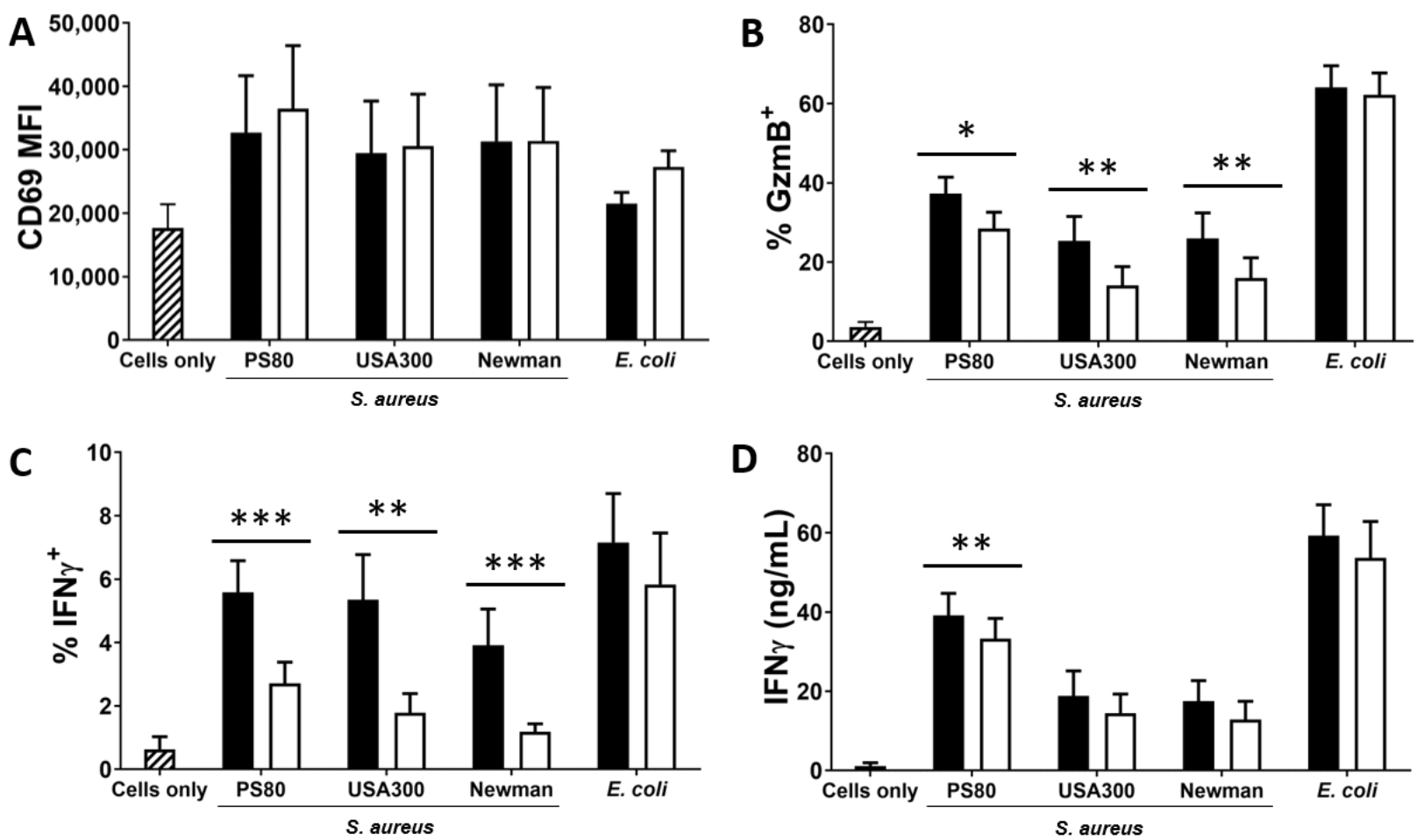

Figure 2. Inhibition of IL-12 results in reduced activation of MAIT cells by S. aureus-infected DCs. DCs $\left(5 \times 10^{5} / \mathrm{mL}\right)$ were infected with $S$. aureus (strains PS80, USA300, Newman) or E. coli (strain EC958) at MOI 10 for $3 \mathrm{~h}$ before elimination of extracellular bacteria by gentamicin treatment. DCs were then co-cultured with MAIT cells $\left(5 \times 10^{5} / \mathrm{mL}\right)$ for $24 \mathrm{~h}$, with or without treatment with anti-IL12 p40 antibodies, or isotype controls (IgG1 $\mathrm{K})$. Cells were treated with BFA for the final $4 \mathrm{~h}$ of culture. Expression of CD69 (A), Granzyme B ('GzmB’) (B), and IFN $\gamma(\mathbf{C})$ by MAIT cells were assessed by flow cytometry, while concentration of IFN $\gamma$ (D) in culture supernatants was assessed by ELISA. Results are expressed as mean fluorescence intensity (MFI) of total live singlet $\mathrm{CD}^{+}$cells + SEM (A), mean \% positive cells within total live singlet $\mathrm{CD}^{+}$cells $+\mathrm{SEM}(\mathrm{B}, \mathrm{C})$, or mean concentration in culture supernatants + SEM (D). $n=5-7$ DC donors per group, $n=8-14$ MAIT cell donors per group. 'Cells only' refers to uninfected cultures. Statistical analysis by pairwise Wilcoxon signed rank test ${ }^{*} p \leq 0.05,{ }^{* *} p \leq 0.01,{ }^{* * *} p \leq 0.001$.

We next assessed the effects of blocking the binding partner for the MAIT TCR, MR1. Previous studies have shown that when MR1 is blocked in MAIT cell co-cultures, activation is reduced, particularly at the earliest timepoints [57,60], suggesting that MR1mediated activation of MAIT cells is both rapid and transitory, and likely replaced by other mechanisms such as IL-12 at later timepoints. We confirmed that MR1 is expressed by DCs and is unaffected by S. aureus infection (Figure S6A). To assess whether DC-expressed MR1 is a key binding partner for the MAIT cell TCR in S. aureus infection, MAIT-DC co-cultures were treated with MR1-blocking Abs and analysed at multiple timepoints. 

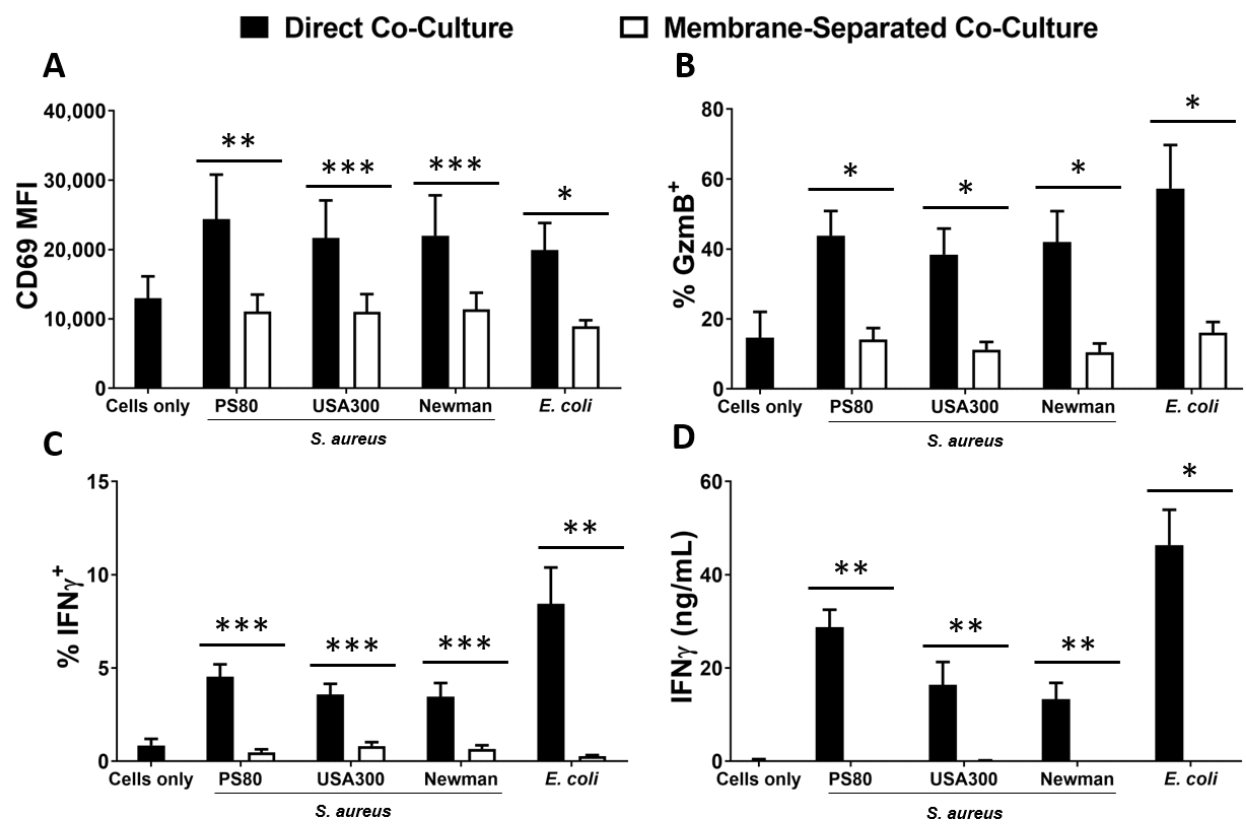

OnM Dasatinib

$\square$ 100nM Dasatinib

E

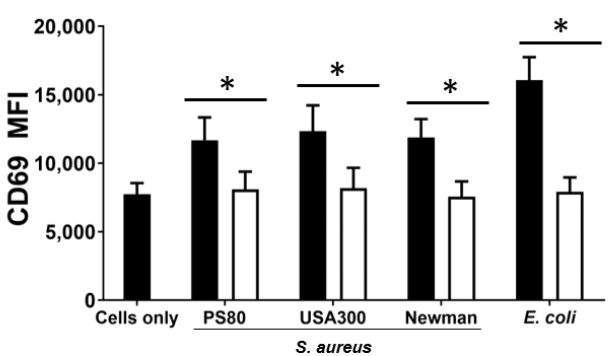

G

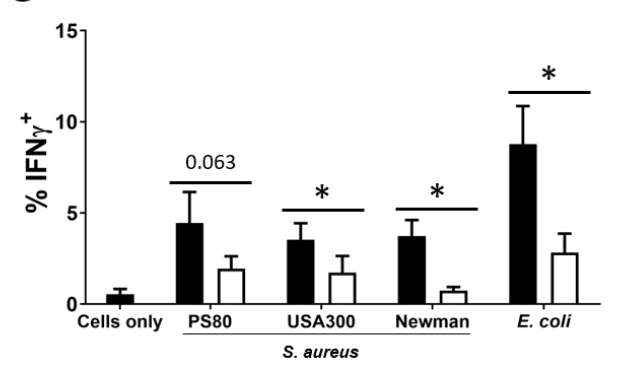

$\mathbf{F}$

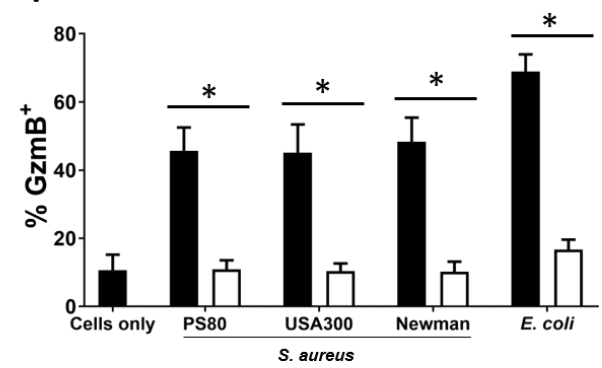

H

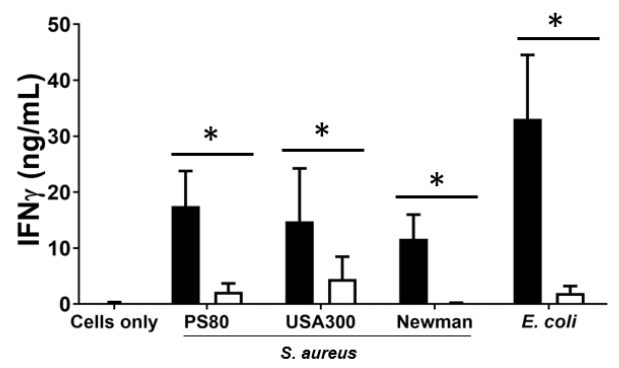

Figure 3. Blocking of cell-cell contact or of TCR signaling eliminates activation of MAIT cells by S. aureus-infected DCs. DCs $\left(5 \times 10^{5} / \mathrm{mL}\right)$ were infected with S. aureus (strains PS80, USA300, Newman) or E. coli (strain EC958) at MOI 10 for $3 \mathrm{~h}$ before elimination of extracellular bacteria by gentamicin treatment. DCs were then co-cultured with MAIT cells $\left(5 \times 10^{5} / \mathrm{mL}\right)$ for $24 \mathrm{~h}$. Co-cultures were carried out in membrane-separated chambers (A-D) or treated with $100 \mathrm{nM}$ Dasatinib (E-H). Cells were treated with BFA for the final $4 \mathrm{~h}$ of culture. Expression of CD69 (A,E), Granzyme B ('GzmB') $(\mathbf{B}, \mathbf{F})$ and IFN $\gamma(\mathbf{C}, \mathbf{G})$ by MAIT cells were assessed by flow cytometry, while concentration of IFN $\gamma(\mathbf{D}, \mathbf{H})$ in culture supernatants was assessed by ELISA. Results are expressed as mean fluorescence intensity (MFI) of total live singlet $\mathrm{CD}^{+}$cells $+\mathrm{SEM}(\mathbf{A}, \mathbf{E})$, mean $\%$ positive cells within total live singlet $\mathrm{CD}^{+}$cells $+\mathrm{SEM}(\mathbf{B}, \mathbf{C}, \mathbf{F}, \mathbf{G})$, or mean concentration in culture supernatants + SEM $(\mathrm{D}, \mathrm{H}) . n=6-10 \mathrm{DC}$ donors per group, $n=7-17$ MAIT cell donors per group. 'Cells only' refers to uninfected cultures. Statistical analysis by pairwise Wilcoxon signed rank test. ${ }^{*} p \leq 0.05,{ }^{* *} p \leq 0.01$, $* * * p \leq 0.001$. 
MR1 blockade non-significantly reduces CD69 (Figure 4A) and significantly reduces Granzyme B (Figure 4C) expression by MAIT cells in response to $S$. aureus, while it appears to delay IFN $\gamma$ expression. In the absence of MR1 blockade, IFN $\gamma$ peaks at $12 \mathrm{~h}$ (Figure 4B), before declining at $24 \mathrm{~h}$. However, the peak for IFN $\gamma$ expression in MR1-blockaded cultures does not occur until $24 \mathrm{~h}$ or afterwards. At $6 \mathrm{~h}$, MR1-blockaded cells display significantly reduced IFN $\gamma$ production, but at $24 \mathrm{~h}$, IFN $\gamma$ production in these cells has recovered, displaying the delayed peak of a slower response (Figure $4 \mathrm{~B}$ ). IFN $\gamma$ production was therefore not completely eliminated by MR1 blockade, but instead it was slowed down, which may be of paramount importance in an acute infection context such as $S$. aureus bacteraemia. Combined treatment with anti-MR1 and anti-IL-12 antibodies appears to further reduce Granzyme B expression at 12 h, (Figure S7) suggesting that IL-12 and MR1 act independently to induce production of this cytotoxic mediator. MR1 blockade significantly reduced E. coli-induced activation of MAIT cells (Figure S6B,C) as has previously been reported [33,59].

\section{S. aureus, $10 \mu \mathrm{g} / \mathrm{mL}$ Isotype Control $\square$ S. aureus, $10 \mu \mathrm{g} / \mathrm{mL}$ Anti-MR1}
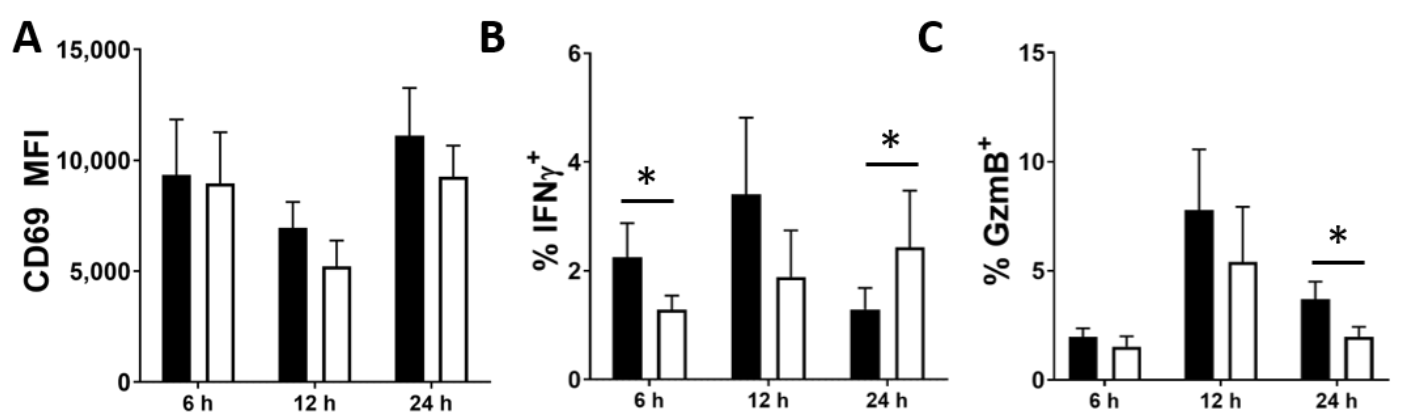

Figure 4. Inhibition of MR1 during S. aureus infection delays MAIT cell activation. DCs $\left(5 \times 10^{5} / \mathrm{mL}\right)$ were infected with $S$. aureus (strain PS80) at MOI 10 for $3 \mathrm{~h}$ before elimination of extracellular bacteria by gentamicin treatment. DCs were then co-cultured with uninfected MAIT cells $\left(5 \times 10^{5} / \mathrm{mL}\right)$ for 6-24 h, with or without treatment with anti-MR1 antibodies or the isotype control (IgG2ak). Cells were treated with BFA for the final $4 \mathrm{~h}$ of culture. Expression of CD69 (A), IFN $\gamma$ (B) and Granzyme B ('GzmB') (C) by MAIT cells were assessed by flow cytometry. Results are expressed as mean fluorescence intensity (MFI) of total live singlet $\mathrm{CD}^{+}$cells + SEM (A) or mean $\%$ positive cells within total live singlet $\mathrm{CD}^{+}$cells $+\mathrm{SEM}(\mathrm{B}, \mathrm{C}) . n=3-6$ DC donors per group, $n=6$ MAIT cell donors per group. 'Cells only' refers to uninfected cultures. Statistical analysis by pairwise Wilcoxon signed rank test, comparing anti-MR1-treated cultures to isotype controls. ${ }^{*} p \leq 0.05$.

In conclusion, these results show that $S$. aureus-induced responses by MAIT cells are controlled both by MR1 and by IL-12. Binding of MR1 by the MAIT TCR induces IFN $\gamma$ within 6 h of exposure to S. aureus-infected DCs, while CD69 and Granzyme B responses, also induced by MR1, become detectable after $6 \mathrm{~h}$. IL-12 released by infected DCs likely acts to enhance expression of CD69, IFN $\gamma$ and Granzyme B by MAIT cells, further arming these cells for tackling $S$. aureus infection.

\subsection{MAIT Cells Mediate Reduced Intracellular Survival of S. aureus}

The adoption of a cytotoxic phenotype by MAIT cells in response to $S$. aureus infection raises the question of whether this represents an immune defence mechanism that can be deployed to control $S$. aureus, given the potential for $S$. aureus to maintain an intracellular lifestyle to promote persistence and dissemination [45-47]. THP-1 cells $\left(5 \times 10^{5}\right.$ cells $\left./ \mathrm{mL}\right)$, which have previously been shown to be a receptive intracellular niche for S. aureus [61-63], were infected with $S$. aureus strain PS80 (a strain with a propensity for intracellular survival $[46,64])$ for $3 \mathrm{~h}$ before gentamicin treatment to eliminate extracellular bacteria. MAIT cells $\left(5 \times 10^{5}\right.$ cells $\left./ \mathrm{mL}\right)$ were then co-cultured with infected THP- 1 cells for $24 \mathrm{~h}$, alongside MAIT cell-free THP-1 cultures. After $24 \mathrm{~h}$, cells were collected and stained with 
anti-Annexin V Abs and PI, or were washed in PBS and lysed with $0.1 \%$ Triton X-100 to enumerate intracellular bacteria. Annexin V staining revealed that MAIT cell co-culture significantly elevates the apoptosis of $S$. aureus-infected THP-1 cells (Figure 5A-C). Using PI to differentiate early and late apoptotic cells, we determined that most apoptotic cells were late apoptotic by $24 \mathrm{~h}$. Analysis of CFUs from cell lysates showed a significant and profound reduction of $S$. aureus persistence in co-cultured THP-1 cells compared to cells cultured without MAIT cells (Figure 5D). These results show clearly that MAIT cells mediate the killing of intracellular $S$. aureus through cytotoxic mechanisms, and could hypothetically make major contributions to the clearance of $S$. aureus infection within the bloodstream.

THP-1 cells only

\section{A Early Apoptosis}

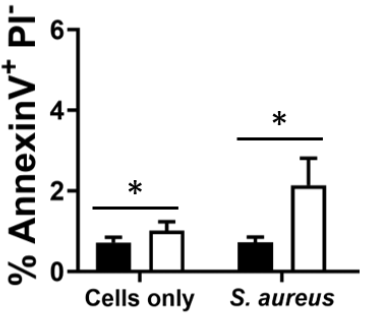

C

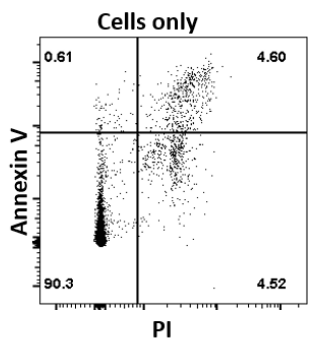

D

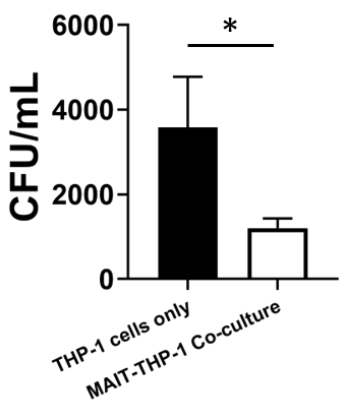

\section{B Late Apoptosis}
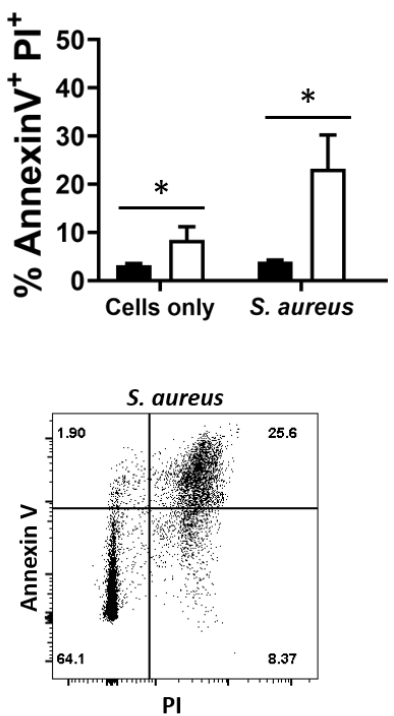

Figure 5. MAIT cells prevent $S$. aureus intracellular survival within THP-1 cells. THP-1 cells $\left(5 \times 10^{5} / \mathrm{mL}\right)$ were infected with S. aureus (strain PS80) at MOI 1 for $3 \mathrm{~h}$ before elimination of extracellular bacteria by gentamicin treatment. THP-1 cells were then either cultured alone or cocultured with uninfected MAIT cells $\left(5 \times 10^{5} / \mathrm{mL}\right)$ for $24 \mathrm{~h}$, after which cells were either collected for analysis of apoptosis by Annexin V and PI staining (A-C) or washed in PBS and lysed in $0.1 \%$ Triton X-100 for $10 \mathrm{~min}$ (D). Lysates were plated on TSA plates and incubated overnight. CFUs were enumerated the following day, and $\mathrm{CFU} / \mathrm{mL}$ of original wells calculated. Results are expressed as mean percentage of apoptotic cells + SEM (A,B) or mean CFU/mL + SEM (D). Representative FACS plots are shown (C). $n=5-6$ MAIT cell donors per group. 'Cells only' refers to uninfected cultures. Statistical analysis by pairwise Wilcoxon signed rank. ${ }^{*} p \leq 0.05$. 


\section{Discussion}

A reduction in circulating MAIT cells is associated with increased susceptibility to a variety of viral and bacterial infections [36], including sepsis [41], and in particular nosocomial infections [41]. Given the dominance of S. aureus as a causative organism of both bacteraemia [65,66] and nosocomial infections [67], a better understanding of the role played by circulating MAIT cells in response to S. aureus is warranted. If MAIT cell deficiencies are linked to $S$. aureus susceptibility, then activation or even adoptive transfer of MAIT cells in S. aureus patients might then be considered as promising new treatment strategies, while vaccination might be expected to see greater success if MAIT cells are targeted. Here we established a model for the activation of bloodstream-derived MAIT cells in response to $S$. aureus. Our assays reveal that MR1, expressed by S. aureus-infected DCs, mediates MAIT cell activation via the TCR, resulting in rapid IFN $\gamma$ production. MR1 also mediates Granzyme B accumulation in activated MAIT cells, while the innate cytokine IL-12 acts to enhance production of both IFN $\gamma$ and Granzyme B. After $24 \mathrm{~h}$, activated MAIT cells produce substantial levels of both the key anti-S. aureus cytokine IFN $\gamma$ and the key cytotoxic mediator Granzyme B. These MAIT cells mediate the killing of THP-1 cells infected with $S$. aureus, with the result that $S$. aureus persistence is strikingly reduced in cultures with MAIT cells. These studies significantly advance our understanding of the breadth of MAIT cell responses to $S$. aureus, with unique insights into their mechanism of activation, cytotoxic responses, and importantly, potency for killing invasive S. aureus.

While MAIT cells in mice are typically scarce, their absence is nonetheless associated with susceptibility to a number of invasive pathogens [34-38,68]; it is natural to wonder if the much larger human MAIT cell compartment might be even more important in human immune responses to infection. In light of repeated failures to transfer protective immunity achieved with $S$. aureus vaccines in mice to human test subjects, it is essential that we develop new assay systems to identify immunological phenomena that may be underrepresented in murine system. MAIT cells, whose frequency is so starkly different between mice and humans, are an obvious case in point.

Human MAIT cells have previously been demonstrated to produce IFN $\gamma[39,69-72]$ following exposure to $S$. aureus or bacterial supernatants. However, these studies have left open the question of how these responses are induced. In addition, the possibility that MAIT cells might also tackle $S$. aureus infections by cytotoxicity has not been addressed. MAIT cells in the bloodstream, with their capacity for rapid MHC-independent activation [55], are ideally suited for rapid elimination of $S$. aureus and the prevention of its dissemination through the bloodstream to distal bodily tissues. The potential for $S$. aureus superantigens to activate MAIT cells for rapid and deleterious inflammatory cytokine responses has been noted [43], and if cytokine production by MAIT cells during S. aureus infection is actually a harmful part of toxic shock syndrome, then this indicates that caution should be exercised if centring innovative clinical solutions around these cells. However, in these superantigen studies, MAIT cell hyperactivation occurred only after exposure to innate cytokines produced by other cells. Our study employed S. aureus strains with disparate superantigen production levels; PS80 is reported to have reduced superantigen expression [73], while USA300 expresses a broad repertoire [74]. In our assays, MAIT cells directly exposed to $S$. aureus bacteria were not activated, suggesting that superantigens alone are not sufficient for robust MAIT cell activation.

Having confirmed the secretion of IFN $\gamma$ and Granzyme B by MAIT cells in co-cultures with $S$. aureus-infected DCs, it was important to assess how these responses are mobilised. We found that both the innate cytokine IL-12 and the TCR-MR1 axis played a part. IL-12 treatment alone does not induce production of IFN $\gamma$ by MAIT cells [57]. Where TCRindependent IFN $\gamma$ expression has been observed (such as during in vitro viral infection), IL-12 neutralisation has no effect on it [58]; instead, it appears that a cocktail of cytokines is required to induce IFN $\gamma$ expression in these circumstances, with IL-18 a critical constituent of such cocktails $[57,58]$. Similarly, IL-15, another key innate cytokine, has been found to trigger IFN $\gamma$ production by MAIT cells in combination with IL-18 [75]. These studies 
suggest that IL-18 is the key ingredient for TCR-independent activation of MAIT cells. IL-18, while crucially important for the activation of MAIT cells during infections by viruses [58,76], including SARS-CoV-2 [40], played no role in the activation of MAIT cells in our assay where $S$. aureus failed to induce any IL-18 production by DCs. In the absence of IL-18 in response to $S$. aureus, IL-12 appears to play a secondary role in our assays; neutralising it weakens activation but does not abolish it. Thus, while our study confirms that IL-12, secreted by S. aureus-infected DCs, plays a role in mediating MAIT cell activation in response to $S$. aureus, our study also confirms that this role is not exclusive.

Instead, the TCR-MR1 axis was found to be crucial for MAIT cell activation. Activation of MR1, the key MAIT TCR ligand, is essential for MAIT cell responses to Fusobacterium nucleatum [77], M. bovis BCG [35], and frequently E. coli, where MR1 blockade has the strongest effect on MAIT cell activation at early timepoints. In co-cultures of MAIT cells with THP-1 cells exposed to formaldehyde- or paraformaldehyde-fixed E. coli, the negative effects of MR1 blockade on MAIT cell activation go from total or near-total at earlier timepoints, to only partial at 20-24 h $[57,60]$. Assays using E. coli-exposed primary monocytes [36,78], macrophages [59] and B cells [33] have shown similar results of MR1 blockade. We recapitulated these results for E. coli-infected DCs, and furthermore showed that the same is at least partially true for $S$. aureus: MR1 blockade significantly reduces MAIT cell IFN $\gamma$ production in response to this pathogen at $6 \mathrm{~h}$ but not at $24 \mathrm{~h}$. In our assay, a picture emerged where $S$. aureus-induced IFN $\gamma$ production commenced rapidly at $6 \mathrm{~h}$ in response to MR1 binding and continued to rise thereafter, but by $24 \mathrm{~h}$ was chiefly controlled by the influence of IL-12, such that MR1 blockade no longer held it back. Clearly, IL-12 neutralisation had a significant dampening effect. Granzyme B production on the other hand was undetectable at $6 \mathrm{~h}$ and only gradually increased over $12-24 \mathrm{~h}$ under the influence of both MR1 and IL-12, such that blocking either of these signals significantly reduced Granzyme B production. These findings emphasised the importance of MR1 binding of the MAIT TCR, particularly at the earliest timepoints, suggesting that riboflavin intermediates known to be produced by staphylococcal metabolism [79] could be a major early activation signal for MAIT cells in the bloodstream. However, it is worth noting that TCR blocking had a profound dampening effect on activation at $24 \mathrm{~h}$ when MR1 blocking did not. While this may be an artefact of the collateral effects of Dasatinib on DCs, it may also suggest that another binding partner for the MAIT TCR may have had a role to play in MAIT cell activation.

Crucially, this is the first report of MAIT cell cytotoxicity marshalled against intracellular S. aureus. Co-culture with S. aureus-infected DCs induced MAIT cell degranulation (measured as CD107a expression), and also production of Granzyme B, a key cytolytic mediator that could be involved in the containment of intracellular $S$. aureus infections. Granzyme B has substantial ability to kill S. aureus directly in vitro [80], and the blocking of neutrophil-expressed Granzyme B prevents the neutrophil-mediated clearance of MRSA in infected mice [81]. S. aureus infection of PBMCs results in upregulation of the degranulation marker CD107a in other cell types [72], supporting the notion that activation of cytotoxic responses against $S$. aureus-infected cells can occur in the systemic circulation. MAIT cells efficiently mediate the death of cells infected with a number of bacteria, including E. coli [82-84], Shigella flexneri [82], H. pylori [85], Mycobacterium smegmatis [86] and Haemophilus influenzae [87], through the expression of Granzyme B. However, while a number of cell types harbouring intracellular bacteria have been shown to be lysed by MAIT cells [82-87], DCs are, to the best of our knowledge, not among them. We demonstrated, at least in the initial $24 \mathrm{~h}$, that cytolysis of S. aureus- and E. coli-infected DCs was minimal, in spite of the clear increase in cytotoxic potential shown by Granzyme B expression. This is likely because activated DCs express high levels of serine protease inhibitor (serpin), which specifically protects them from the effects of Granzyme B [88]. This resistance is enhanced by co-culture with $\mathrm{T}_{h} 1$ cells [88]; MAIT cells in our assays showed a pronounced IFN $\gamma$-producing phenotype, and it is therefore quite possible that these cells may also have mediated enhanced DC resistance to Granzyme B. Our experiments instead employed 
THP-1 cells to assess MAIT cell cytotoxicity, being that these cells are notable intracellular niches for S. aureus survival [61,62], and we found that MAIT cell co-culture significantly heightened apoptosis of infected cells, resulting in a roughly threefold reduction in the persistence of intracellular S. aureus. It is worth noting that this may not exclusively be a result of cytotoxicity, but also of the MAIT cells' substantial IFN $\gamma$ expression. Among a number of specific roles in fighting S. aureus infection, including macrophage activation [17] and neutrophil survival [21], IFN $\gamma$ frequently licences infected cells to overcome blocks on intracellular killing; for example, macrophages kill intracellular $S$. aureus much more efficiently if treated with IFN $\gamma$ [20], and MAIT cells specifically have been shown to limit intracellular growth of M. bovis in infected macrophages via IFN $\gamma$ secretion [35]. However, we believe that the profound cytotoxic effects of MAIT cells, demonstrated by Annexin V staining data, heavily imply that this mechanism takes precedence over IFN $\gamma$-mediated S. aureus killing. Notably, both of these potential mechanisms-S. aureus elimination mediated either by cytotoxic mediators or by IFN $\gamma$-are likely to be dependent on IL-12 secretion by infected cells and direct TCR binding by MR1, in light of our findings that Granzyme B and IFN $\gamma$ rely on both of these signals for deployment.

It has been suggested that in vitro-expanded MAIT cells could be administered to patients suffering bacteraemia and other severe infections in order to alleviate both primary infections and sequelae [89]. The data presented here add to this case, and add S. aureus to the list of potential targets. Their broad effector functions have also provoked the suggestion of targeting MAIT cells for vaccination [90]. In a specific murine vaccination trial, clearance of L. longbeachae was enhanced in mice following immunization with the key MR1 ligand 5-OP-RU in combination with IL-23, highlighting a potential role for targeting MAIT cells in vaccination trials [91]. During controlled infection of human volunteers with S. enterica serovar Paratyphi A, MAIT cells undergo clonal expansion, and expanded clonotypes show greater in vitro activation, suggesting a memory-like phenomenon [92]. Most recently, MR1 deficiency in mice resulted in defective responses by total CD8 ${ }^{+} \mathrm{T}$ cells to the ChAdOx1 SARS-CoV-2 vaccine [93]. These studies demonstrate that as we learn more about MAIT cells, their potential as targets for advanced next generation S. aureus treatments becomes clearer.

Taken together, these findings reveal the important effector responses of MAIT cells in response to S. aureus, and clarify the precise mechanisms and time course of that response. MAIT cells have unique characteristics that make them attractive tools for novel S. aureus therapies, and their powerful contributions to both IFN $\gamma$ and cytotoxic responses have clear relevance for defence against this devastating infection, raising the possibility of administering them as treatments during infection, or of targeting them in next generation vaccine trials. The hunt for an $S$. aureus vaccine requires unconventional thinking, and these unconventional $\mathrm{T}$ cells should no longer be overlooked.

Supplementary Materials: The following are available online at https:/ / www.mdpi.com/article/10.3 390/microorganisms10010148/s1, Figure S1: The majority of human blood-derived MAIT cells are $\mathrm{CD}^{+} \mathrm{CD}^{-}$and $\mathrm{CD} 161^{\text {hi }}$. Figure S2: Human blood-derived MAIT cells in co-culture with S. aureusinfected DCs express TNF. Figure S3: Activated MAIT cells do not directly kill DCs at 24 h. Figure S4: S. aureus induces IL-12 secretion and not IL-18 secretion by DCs. Figure S5: Treatment with Dasatinib has minor effects on DC activation and no effect on viability. Figure S6: S. aureus-infected DCs express MR1, and inhibition of MR1 during E. coli infection reduces MAIT cell activation. Figure S7: Combined blocking of MR1 and IL-12 further decreases Granzyme B expression by MAIT cells in response to $S$. aureus-infected DCs at $12 \mathrm{~h}$.

Author Contributions: Study conceptualization, A.J.R.C. and R.M.M.; methodologies, A.J.R.C., J.C., F.C.C.; formal analysis, A.J.R.C., A.E.H., R.M.M.; writing-original draft preparation, A.J.R.C.; writing —review and editing, A.E.H., R.M.M.; supervision, R.M.M.; project administration, R.M.M.; funding acquisition, R.M.M. All authors have read and agreed to the published version of the manuscript.

Funding: This work was funded by a Science Foundation Ireland Investigator Award (15/IA/3041) and a Science Foundation Ireland ERC Development Award (17/ERCD/5345) to RMM. 


\section{Institutional Review Board Statement: Not applicable.}

Informed Consent Statement: Not applicable.

Acknowledgments: The authors would like to thank the NIH tetramer core facility for provision of MR1-peptide complexes. The MR1 tetramer technology was developed jointly by James McCluskey, Jamie Rossjohn, and David Fairlie, and the material was produced by the NIH Tetramer Core Facility as permitted to be distributed by the University of Melbourne. We also thank the Irish Blood Transfusion Service for provision of buffy coats, Barry Moran for flow cytometry expertise, and Stephen Smith for provision of E. coli strain EC958.

Conflicts of Interest: J.C. is currently a PhD fellow participating in a postgraduate studentship program at GlaxoSmithKline.

\section{References}

1. Kern, W.; Rieg, S. Burden of bacterial bloodstream infection-A brief update on epidemiology and significance of multidrugresistant pathogens. Clin. Microbiol. Infect. 2020, 26, 151-157. [CrossRef] [PubMed]

2. Asgeirsson, H.; Thalme, A.; Weiland, O. Staphylococcus aureus bacteraemia and endocarditis—Epidemiology and outcome: A review. Infect. Dis. 2018, 50, 175-192. [CrossRef] [PubMed]

3. Kwiecinski, J.M.; Horswill, A.R. Staphylococcus aureus bloodstream infections: Pathogenesis and regulatory mechanisms. Curr. Opin. Microbiol. 2020, 53, 51-60. [CrossRef] [PubMed]

4. Chambers, H.F.; DeLeo, F.R. Waves of resistance: Staphylococcus aureus in the antibiotic era. Nat. Rev. Microbiol. 2009, 7, 629-641. [CrossRef]

5. Clegg, J.; Soldaini, E.; McLoughlin, R.M.; Rittenhouse, S.; Bagnoli, F.; Phogat, S. Staphylococcus aureus Vaccine Research and Development: The Past, Present and Future, Including Novel Therapeutic Strategies. Front. Immunol. 2021, 12. [CrossRef] [PubMed]

6. McNeely, T.B.; Shah, N.A.; Fridman, A.; Joshi, A.; Hartzel, J.S.; Keshari, R.S.; Lupu, F.; DiNubile, M.J. Mortality among recipients of the Merck V710 Staphylococcus aureus vaccine after postoperative S. aureus infections: An analysis of possible contributing host factors. Hum. Vaccines Immunother. 2014, 10, 3513-3516. [CrossRef]

7. Fattom, A.; Matalon, A.; Buerkert, J.; Taylor, K.; Damaso, S.; Boutriau, D. Efficacy profile of a bivalent Staphylococcus aureusglycoconjugated vaccine in adults on hemodialysis: Phase III randomized study. Hum. Vaccines Immunother. 2015, 11, 632-641. [CrossRef]

8. Miller, L.S.; Fowler, V.G.; Shukla, S.K.; Rose, W.E.; Proctor, R.A. Development of a vaccine against Staphylococcus aureus invasive infections: Evidence based on human immunity, genetics and bacterial evasion mechanisms. FEMS Microbiol. Rev. 2020, 44, 123-153. [CrossRef]

9. O'Brien, E.C.; McLoughlin, R.M. Considering the 'Alternatives' for Next-Generation Anti-Staphylococcus aureus Vaccine Development. Trends Mol. Med. 2019, 25, 171-184. [CrossRef]

10. Scully, I.; Timofeyeva, Y.; Illenberger, A.; Lu, P.; Liberator, P.; Jansen, K.; Anderson, A. Performance of a Four-Antigen Staphylococcus aureus Vaccine in Preclinical Models of Invasive S. aureus Disease. Microorganisms 2021, 9, 177. [CrossRef]

11. Redi, D.; Raffaelli, C.S.; Rossetti, B.; De Luca, A.; Montagnani, F. Staphylococcus aureus vaccine preclinical and clinical development: Current state of the art. New Microbiol. 2018, 41, 208-213.

12. Armentrout, E.I.; Liu, G.Y.; Martins, G.A. T Cell Immunity and the Quest for Protective Vaccines against Staphylococcus aureus Infection. Microorganisms 2020, 8, 1936. [CrossRef] [PubMed]

13. Wiese, L.; Mejer, N.; Schønheyder, H.; Westh, H.; Jensen, A.; Larsen, A.R.; Skov, R.; Benfield, T. A nationwide study of comorbidity and risk of reinfection after Staphylococcus aureus bacteraemia. J. Infect. 2013, 67, 199-205. [CrossRef] [PubMed]

14. Laupland, K.B.; Ross, T.; Gregson, D.B. Staphylococcus aureusBloodstream Infections: Risk Factors, Outcomes, and the Influence of Methicillin Resistance in Calgary, Canada, 2000-2006. J. Infect. Dis. 2008, 198, 336-343. [CrossRef]

15. Holland, S.; DeLeo, F.R.; Elloumi, H.Z.; Hsu, A.P.; Uzel, G.; Brodsky, N.; Freeman, A.F.; Demidowich, A.; Davis, J.; Turner, M.L.C.; et al. STAT3 Mutations in the Hyper-IgE Syndrome. N. Engl. J. Med. 2007, 357, 1608-1619. [CrossRef]

16. Minegishi, Y.; Saito, M.; Nagasawa, M.; Takada, H.; Hara, T.; Tsuchiya, S.; Agematsu, K.; Yamada, M.; Kawamura, N.; Ariga, T.; et al. Molecular explanation for the contradiction between systemic Th17 defect and localized bacterial infection in hyper-IgE syndrome. J. Exp. Med. 2009, 206, 1291-1301. [CrossRef]

17. Decker, T.; Stockinger, S.; Karaghiosoff, M.; Müller, M.; Kovarik, P. IFNs and STATs in innate immunity to microorganisms. J. Clin. Investig. 2002, 109, 1271-1277. [CrossRef]

18. Brown, A.F.; Murphy, A.; Lalor, S.; Leech, J.M.; O’Keeffe, K.M.; Mac Aogáin, M.; O’Halloran, D.P.; Lacey, K.; Tavakol, M.; Hearnden, C.H.; et al. Memory Th1 Cells Are Protective in Invasive Staphylococcus aureus Infection. PLoS Pathog. 2015, 11, e1005226. [CrossRef]

19. Pelletier, M.; Maggi, L.; Micheletti, A.; Lazzeri, E.; Tamassia, N.; Costantini, C.; Cosmi, L.; Lunardi, C.; Annunziato, F.; Romagnani, S.; et al. Evidence for a cross-talk between human neutrophils and Th17 cells. Blood 2010, 115, 335-343. [CrossRef] [PubMed] 
20. Kubica, M.; Guzik, K.; Koziel, J.; Zarebski, M.; Richter, W.; Gajkowska, B.; Golda, A.; Maciag-Gudowska, A.; Brix, K.; Shaw, L.; et al. A Potential New Pathway for Staphylococcus aureus Dissemination: The Silent Survival of S. aureus Phagocytosed by Human Monocyte-Derived Macrophages. PLoS ONE 2008, 3, e1409. [CrossRef]

21. Bröker, B.M.; Mrochen, D.; Péton, V. The T Cell Response to Staphylococcus aureus. Pathogens 2016, 5, 31. [CrossRef]

22. Cooper, A.J.R.; Lalor, S.J.; McLoughlin, R.M. Activation of Human V $\delta 2+\gamma \delta$ T Cells by Staphylococcus aureus Promotes Enhanced Anti-Staphylococcal Adaptive Immunity. J. Immunol. 2020, 205, 1039-1049. [CrossRef] [PubMed]

23. Cho, J.S.; Pietras, E.M.; Garcia, N.C.; Ramos, R.I.; Farzam, D.M.; Monroe, H.R.; Magorien, J.E.; Blauvelt, A.; Kolls, J.K.; Cheung, A.L.; et al. IL-17 is essential for host defense against cutaneous Staphylococcus aureus infection in mice. J. Clin. Investig. 2010, 120, 1762-1773. [CrossRef]

24. Cheng, P.; Liu, T.; Zhou, W.-Y.; Zhuang, Y.; Peng, L.-S.; Zhang, J.-Y.; Yin, Z.-N.; Mao, X.-H.; Guo, G.; Shi, Y.; et al. Role of gamma-delta T cells in host response against Staphylococcus aureus-induced pneumonia. BMC Immunol. 2012, 13, 38. [CrossRef]

25. Maher, B.M.; Mulcahy, M.E.; Murphy, A.G.; Wilk, M.; O’Keeffe, K.M.; Geoghegan, J.A.; Lavelle, E.C.; McLoughlin, R.M. Nlrp-3Driven Interleukin 17 Production by $\gamma \delta \mathrm{T}$ Cells Controls Infection Outcomes during Staphylococcus aureus Surgical Site Infection. Infect. Immun. 2013, 81, 4478-4489. [CrossRef]

26. Murphy, A.G.; O'Keeffe, K.M.; Lalor, S.; Maher, B.M.; Mills, K.; McLoughlin, R.M. Staphylococcus aureusInfection of Mice Expands a Population of Memory $\gamma \delta$ T Cells That Are Protective against Subsequent Infection. J. Immunol. 2014, 192, 3697-3708. [CrossRef]

27. Dillen, C.A.; Pinsker, B.L.; Marusina, A.I.; Merleev, A.A.; Farber, O.N.; Liu, H.; Archer, N.; Lee, D.B.; Wang, Y.; Ortines, R.V.; et al. Clonally expanded $\gamma \delta$ T cells protect against Staphylococcus aureus skin reinfection. J. Clin. Investig. 2018, 128, 1026-1042. [CrossRef]

28. Amini, A.; Pang, D.; Hackstein, C.-P.; Klenerman, P. MAIT Cells in Barrier Tissues: Lessons from Immediate Neighbors. Front. Immunol. 2020, 11, 584521. [CrossRef] [PubMed]

29. Rahimpour, A.; Koay, H.-F.; Enders, A.; Clanchy, R.; Eckle, S.; Meehan, B.; Chen, Z.; Whittle, B.; Liu, L.; Fairlie, D.; et al. Identification of phenotypically and functionally heterogeneous mouse mucosal-associated invariant $\mathrm{T}$ cells using MR1 tetramers. J. Exp. Med. 2015, 212, 1095-1108. [CrossRef] [PubMed]

30. Martin, E.; Treiner, E.; Duban, L.; Guerri, L.; Laude, H.; Toly, C.; Premel, V.; Devys, A.; Moura, I.C.; Tilloy, F.; et al. Stepwise Development of MAIT Cells in Mouse and Human. PLoS Biol. 2009, 7, e1000054. [CrossRef]

31. Corbett, A.; Eckle, S.; Birkinshaw, R.; Liu, L.; Patel, O.; Mahony, J.; Chen, Z.; Reantragoon, R.; Meehan, B.; Cao, H.; et al. T-cell activation by transitory neo-antigens derived from distinct microbial pathways. Nature 2014, 509, 361-365. [CrossRef]

32. Kjer-Nielsen, L.; Patel, O.; Corbett, A.; Le Nours, J.; Meehan, B.; Liu, L.; Bhati, M.; Chen, Z.; Kostenko, L.; Reantragoon, R.; et al. MR1 presents microbial vitamin B metabolites to MAIT cells. Nature 2012, 491, 717-723. [CrossRef]

33. Salerno-Goncalves, R.; Rezwan, T.; Sztein, M.B. B Cells Modulate Mucosal Associated Invariant T Cell Immune Responses. Front. Immunol. 2014, 4, 511. [CrossRef] [PubMed]

34. Georgel, P.; Radosavljevic, M.; Macquin, C.; Bahram, S. The non-conventional MHC class I MR1 molecule controls infection by Klebsiella pneumoniae in mice. Mol. Immunol. 2011, 48, 769-775. [CrossRef] [PubMed]

35. Chua, W.-J.; Truscott, S.M.; Eickhoff, C.S.; Blazevic, A.; Hoft, D.F.; Hansen, T.H. Polyclonal MAIT cells have unique innate functions in bacterial infection. Infect. Immun. 2012, 80. [CrossRef] [PubMed]

36. Le Bourhis, L.; Martin, E.; Péguillet, I.; Guihot, A.; Froux, N.; Coré, M.; Lévy, E.; Dusseaux, M.; Meyssonnier, V.; Premel, V.; et al. Antimicrobial activity of mucosal-associated invariant T cells. Nat. Immunol. 2010, 11, 701-708. [CrossRef]

37. Wang, H.; Dsouza, C.; Lim, X.Y.; Kostenko, L.; Pediongco, T.J.; Eckle, S.B.G.; Meehan, B.S.; Shi, M.; Wang, N.; Li, S.; et al. MAIT cells protect against pulmonary Legionella longbeachae infection. Nat. Commun. 2018, 9, 3350. [CrossRef]

38. Trivedi, S.; Labuz, D.; Anderson, C.P.; Araujo, C.V.; Blair, A.; Middleton, E.A.; Jensen, O.; Tran, A.; Mulvey, M.A.; Campbell, R.A.; et al. Mucosal-associated invariant T (MAIT) cells mediate protective host responses in sepsis. eLife 2020, 9, e55615. [CrossRef]

39. Gold, M.C.; Cerri, S.; Smyk-Pearson, S.; Cansler, M.E.; Vogt, T.M.; Delepine, J.; Winata, E.; Swarbrick, G.M.; Chua, W.-J.; Yu, Y.Y.L.; et al. Human Mucosal Associated Invariant T Cells Detect Bacterially Infected Cells. PLoS Biol. 2010, 8, e1000407. [CrossRef]

40. Flament, H.; Rouland, M.; Beaudoin, L.; Toubal, A.; Bertrand, L.; Lebourgeois, S.; Gouda, Z.; Rousseau, C.; Soulard, P.; HurtadoNedelec, M.; et al. Outcome of SARS-CoV-2 infection linked to MAIT cell activation and cytotoxicity: Evidence for an IL-18 dependent mechanism. medRxiv 2020. [CrossRef]

41. Grimaldi, D.; Le Bourhis, L.; Sauneuf, B.; Dechartres, A.; Rousseau, C.; Ouaaz, F.; Milder, M.; Louis, D.; Chiche, J.-D.; Mira, J.-P.; et al. Specific MAIT cell behaviour among innate-like T lymphocytes in critically ill patients with severe infections. Intensiv. Care Med. 2014, 40, 192-201. [CrossRef]

42. Sandberg, J.K.; Norrby-Teglund, A.; Leeansyah, E. Bacterial deception of MAIT cells in a cloud of superantigen and cytokines PLoS Biol. 2017, 15, e2003167. [CrossRef]

43. Shaler, C.R.; Choi, J.; Rudak, P.T.; Memarnejadian, A.; Szabo, P.A.; Tun-Abraham, M.E.; Rossjohn, J.; Corbett, A.; McCluskey, J.; McCormick, J.; et al. MAIT cells launch a rapid, robust and distinct hyperinflammatory response to bacterial superantigens and quickly acquire an anergic phenotype that impedes their cognate antimicrobial function: Defining a novel mechanism of superantigen-induced immunopathology and immunosuppression. PLoS Biol. 2017, 15, e2001930. [CrossRef] 
44. Greenberg, J.A.; Hrusch, C.L.; Jaffery, M.R.; David, M.Z.; Daum, R.S.; Hall, J.B.; Kress, J.P.; Sperling, A.I.; Verhoef, P.A. Distinct T-helper cell responses to Staphylococcus aureus bacteremia reflect immunologic comorbidities and correlate with mortality. Crit. Care 2018, 22, 107. [CrossRef] [PubMed]

45. Garzoni, C.; Kelley, W.L. Staphylococcus aureus: New evidence for intracellular persistence. Trends Microbiol. 2009, 17, 59-65. [CrossRef]

46. Mulcahy, M.E.; O’Brien, E.C.; O'Keeffe, K.M.; Vozza, E.G.; Leddy, N.; McLoughlin, R.M. Manipulation of Autophagy and Apoptosis Facilitates Intracellular Survival of Staphylococcus aureus in Human Neutrophils. Front. Immunol. 2020, 11, 11. [CrossRef]

47. Thwaites, G.E.; Gant, V. Are bloodstream leukocytes Trojan Horses for the metastasis of Staphylococcus aureus? Nat. Rev. Genet. 2011, 9, 215-222. [CrossRef]

48. Melo, A.; O’Brien, A.M.; Phelan, J.J.; Kennedy, S.; Wood, N.A.W.; Veerapen, N.; Besra, G.S.; Clarke, N.E.; Foley, E.K.; Ravi, A.; et al. Mucosal-Associated Invariant T Cells Display Diminished Effector Capacity in Oesophageal Adenocarcinoma. Front. Immunol. 2019, 10, 1580. [CrossRef] [PubMed]

49. ECACC General Cell Collection: THP 1 (Product Information Page). Available online: https://www.phe-culturecollections.org. $\mathrm{uk} /$ products / celllines / generalcell/detail.jsp?refld=88081201\&collection=ecacc_gc (accessed on 30 November 2021).

50. Asheshov, E.H. The Genetics of Penicillinase Production in Staphylococcus aureus Strain PS 80. J. Gen. Microbiol. 1969, 59, $289-301$. [CrossRef] [PubMed]

51. Diep, B.A.; Gill, S.R.; Chang, R.F.; Phan, T.H.; Chen, J.H.; Davidson, M.G.; Lin, F.; Lin, J.; Carleton, H.A.; Mongodin, E.F.; et al. Complete genome sequence of USA300, an epidemic clone of community-acquired meticillin-resistant Staphylococcus aureus. Lancet 2006, 367, 731-739. [CrossRef]

52. Duthie, E.S.; Lorenz, L.L. Staphylococcal Coagulase: Mode of Action and Antigenicity. J. Gen. Microbiol. 1952, 6, 95-107. [CrossRef]

53. Forde, B.M.; BEN Zakour, N.; Stanton-Cook, M.; Phan, M.-D.; Totsika, M.; Peters, K.M.; Chan, K.G.; Schembri, M.; Upton, M.; Beatson, S.A. The Complete Genome Sequence of Escherichia coli EC958: A High Quality Reference Sequence for the Globally Disseminated Multidrug Resistant E. coli O25b:H4-ST131 Clone. PLoS ONE 2014, 9, e104400. [CrossRef]

54. Schade, A.E.; Schieven, G.L.; Townsend, R.; Jankowska, A.M.; Susulic, V.; Zhang, R.; Szpurka, H.; Maciejewski, J.P. Dasatinib, a small-molecule protein tyrosine kinase inhibitor, inhibits T-cell activation and proliferation. Blood 2008, 111, 1366-1377. [CrossRef] [PubMed]

55. Godfrey, D.I.; Koay, H.-F.; McCluskey, J.; Gherardin, N. The biology and functional importance of MAIT cells. Nat. Immunol. 2019, 20, 1110-1128. [CrossRef]

56. Turtle, C.J.; Delrow, J.; Joslyn, R.C.; Swanson, H.M.; Basom, R.; Tabellini, L.; Delaney, C.; Heimfeld, S.; Hansen, J.A.; Riddell, S.R. Innate signals overcome acquired TCR signaling pathway regulation and govern the fate of human CD161hi CD8 $\alpha+$ semi-invariant T cells. Blood 2011, 118, 2752-2762. [CrossRef]

57. Ussher, J.E.; Bilton, M.; Attwod, E.; Shadwell, J.; Richardson, R.; de Lara, C.; Mettke, E.; Kurioka, A.; Hansen, T.H.; Klenerman, P.; et al. CD $161++$ CD $8+$ T cells, including the MAIT cell subset, are specifically activated by IL - $12+$ IL -18 in a TCR -independent manner. Eur. J. Immunol. 2014, 44, 195-203. [CrossRef] [PubMed]

58. Van Wilgenburg, B.; Scherwitzl, I.; Hutchinson, E.C.; Leng, T.; Kurioka, A.; Kulicke, C.; De Lara, C.; Cole, S.; Vasanawathana, S.; Limpitikul, W.; et al. MAIT cells are activated during human viral infections. Nat. Commun. 2016, 7, 11653. [CrossRef] [PubMed]

59. Jeffery, H.C.; van Wilgenburg, B.; Kurioka, A.; Parekh, K.; Stirling, K.; Roberts, S.; Dutton, E.E.; Hunter, S.; Geh, D.; Braitch, M.K.; et al. Biliary epithelium and liver B cells exposed to bacteria activate intrahepatic MAIT cells through MR1. J. Hepatol. 2016, 64, 1118-1127. [CrossRef]

60. Lamichhane, R.; Schneider, M.; De La Harpe, S.M.; Harrop, T.W.; Hannaway, R.F.; Dearden, P.; Kirman, J.; Tyndall, J.D.; Vernall, A.J.; Ussher, J.E. TCR- or Cytokine-Activated CD8+ Mucosal-Associated Invariant T Cells Are Rapid Polyfunctional Effectors That Can Coordinate Immune Responses. Cell Rep. 2019, 28, 3061-3076.e5. [CrossRef] [PubMed]

61. Brinch, K.S.; Sandberg, A.; Baudoux, P.; Van Bambeke, F.; Tulkens, P.; Frimodt-Møller, N.; Høiby, N.; Kristensen, H.-H. Plectasin Shows Intracellular Activity against Staphylococcus aureus in Human THP-1 Monocytes and in a Mouse Peritonitis Model. Antimicrob. Agents Chemother. 2009, 53, 4801-4808. [CrossRef]

62. Brinch, K.S.; Tulkens, P.M.; Van Bambeke, F.; Frimodt-Møller, N.; Høiby, N.; Kristensen, H.-H. Intracellular activity of the peptide antibiotic NZ2114: Studies with Staphylococcus aureus and human THP-1 monocytes, and comparison with daptomycin and vancomycin. J. Antimicrob. Chemother. 2010, 65, 1720-1724. [CrossRef]

63. Musilova, J.; Mulcahy, M.E.; Kuijk, M.M.; McLoughlin, R.M.; Bowie, A.G. Toll-like receptor 2-dependent endosomal signaling by Staphylococcus aureus in monocytes induces type I interferon and promotes intracellular survival. J. Biol. Chem. 2019, 294, 17031-17042. [CrossRef]

64. O'Keeffe, K.M.; Wilk, M.M.; Leech, J.M.; Murphy, A.G.; Laabei, M.; Monk, I.R.; Massey, R.C.; Lindsay, J.; Foster, T.J.; Geoghegan, J.A.; et al. Manipulation of Autophagy in Phagocytes Facilitates Staphylococcus aureus Bloodstream Infection. Infect. Immun. 2015, 83, 3445-3457. [CrossRef]

65. Melzer, M.; Welch, C. Thirty-day mortality in UK patients with community-onset and hospital-acquired meticillin-susceptible Staphylococcus aureus bacteraemia. J. Hosp. Infect. 2013, 84, 143-150. [CrossRef] 
66. Turnidge, J.D.; Kotsanas, D.; Munckhof, W.; Roberts, S.; Bennett, C.M.; Nimmo, G.R.; Coombs, G.W.; Murray, R.J.; Howden, B.; Johnson, P.D.R.; et al. Staphylococcus aureus bacteraemia: A major cause of mortality in Australia and New Zealand. Med. J. Aust. 2009, 191, 368-373. [CrossRef]

67. Weiner, L.M.; Webb, A.K.; Limbago, B.; Dudeck, M.A.; Patel, J.; Kallen, A.J.; Edwards, J.R.; Sievert, D.M. Antimicrobial-Resistant Pathogens Associated With Healthcare-Associated Infections: Summary of Data Reported to the National Healthcare Safety Network at the Centers for Disease Control and Prevention, 2011-2014. Infect. Control Hosp. Epidemiol. 2016, 37, $1288-1301$. [CrossRef]

68. Meierovics, A.; Yankelevich, W.-J.; Cowley, S.C. MAIT cells are critical for optimal mucosal immune responses during in vivo pulmonary bacterial infection. Proc. Natl. Acad. Sci. USA 2013, 110, E3119-E3128. [CrossRef]

69. Meermeier, E.; Laugel, B.F.; Sewell, A.; Corbett, A.; Rossjohn, J.; McCluskey, J.; Harriff, M.J.; Franks, T.; Gold, M.C.; Lewinsohn, D.M. Human TRAV1-2-negative MR1-restricted T cells detect $S$. pyogenes and alternatives to MAIT riboflavin-based antigens. Nat. Commun. 2016, 7, 12506. [CrossRef] [PubMed]

70. Lepore, M.; Kalinichenko, A.; Colone, A.; Paleja, B.; Singhal, A.; Tschumi, A.; Lee, B.; Poidinger, M.; Zolezzi, F.; Quagliata, L.; et al. Parallel T-cell cloning and deep sequencing of human MAIT cells reveal stable oligoclonal TCR $\beta$ repertoire. Nat. Commun. 2014, 5, 3866. [CrossRef] [PubMed]

71. Davey, M.; Morgan, M.P.; Liuzzi, A.R.; Tyler, C.J.; Khan, M.W.A.; Szakmany, T.; Hall, J.E.; Moser, B.; Eberl, M. Microbe-Specific Unconventional T Cells Induce Human Neutrophil Differentiation into Antigen Cross-Presenting Cells. J. Immunol. 2014, 193, 3704-3716. [CrossRef] [PubMed]

72. Johansson, M.A.; Björkander, S.; Forsberg, M.M.; Qazi, K.R.; Celades, M.S.; Bittmann, J.; Eberl, M.; Sverremark-Ekström, E. Probiotic Lactobacilli Modulate Staphylococcus aureus-Induced Activation of Conventional and Unconventional T cells and NK Cells. Front. Immunol. 2016, 7, 273. [CrossRef]

73. Tzianabos, A.O.; Wang, J.Y.; Lee, J. Structural rationale for the modulation of abscess formation by Staphylococcus aureus capsular polysaccharides. Proc. Natl. Acad. Sci. USA 2001, 98, 9365-9370. [CrossRef]

74. Parker, D.; Ryan, C.L.; Alonzo, F., 3rd; Torres, V.J.; Planet, P.J.; Prince, A.S. CD4+ T cells promote the pathogenesis of Staphylococcus aureus pneumonia. J. Infect. Dis. 2015, 211, 835-845. [CrossRef]

75. Sattler, A.; Dang-Heine, C.; Reinke, P.; Babel, N. IL-15 dependent induction of IL-18 secretion as a feedback mechanism controlling human MAIT-cell effector functions. Eur. J. Immunol. 2015, 45, 2286-2298. [CrossRef]

76. Ussher, J.E.; Willberg, C.B.; Klenerman, P. MAIT cells and viruses. Immunol. Cell Biol. 2018, 96, 630-641. [CrossRef] [PubMed]

77. Li, S.; Simoni, Y.; Becht, E.; Loh, C.Y.; Li, N.; Lachance, D.; Koo, S.-L.; Lim, T.P.; Tan, E.K.W.; Mathew, R.; et al. Human TumorInfiltrating MAIT Cells Display Hallmarks of Bacterial Antigen Recognition in Colorectal Cancer. Cell Rep. Med. 2020, 1, 100039. [CrossRef]

78. Jo, J.; Tan, A.T.; Ussher, J.; Sandalova, E.; Tang, X.-Z.; Tan-Garcia, A.; To, N.; Hong, M.; Chia, A.; Gill, U.S.; et al. Toll-Like Receptor 8 Agonist and Bacteria Trigger Potent Activation of Innate Immune Cells in Human Liver. PLoS Pathog. 2014, 10, e1004210. [CrossRef]

79. Wang, H.; Mann, P.A.; Xiao, L.; Gill, C.; Galgoci, A.M.; Howe, J.A.; Villafania, A.; Barbieri, C.M.; Malinverni, J.C.; Sher, X.; et al. Dual-Targeting Small-Molecule Inhibitors of the Staphylococcus aureus FMN Riboswitch Disrupt Riboflavin Homeostasis in an Infectious Setting. Cell Chem. Biol. 2017, 24, 576-588.e6. [CrossRef]

80. Shafer, W.M.; Pohl, J.; Onunka, V.C.; Bangalore, N.; Travis, J. Human lysosomal cathepsin G and granzyme B share a functionally conserved broad spectrum antibacterial peptide. J. Biol. Chem. 1991, 266, 112-116. [CrossRef]

81. Spolski, R.; West, E.E.; Li, P.; Veenbergen, S.; Yung, S.; Kazemian, M.; Oh, J.; Yu, Z.-X.; Freeman, A.F.; Holland, S.M.; et al. IL-21/type I interferon interplay regulates neutrophil-dependent innate immune responses to Staphylococcus aureus. eLife 2019, 8, e45501. [CrossRef] [PubMed]

82. Le Bourhis, L.; Dusseaux, M.; Bohineust, A.; Bessoles, S.; Martin, E.; Premel, V.; Coré, M.; Sleurs, D.; Serriari, N.-E.; Treiner, E.; et al. MAIT Cells Detect and Efficiently Lyse Bacterially-Infected Epithelial Cells. PLoS Pathog. 2013, 9, e1003681. [CrossRef] [PubMed]

83. Leeansyah, E.; Svärd, J.; Dias, J.; Buggert, M.; Nyström, J.; Quigley, M.F.; Moll, M.; Sönnerborg, A.; Nowak, P.; Sandberg, J.K. Arming of MAIT Cell Cytolytic Antimicrobial Activity Is Induced by IL-7 and Defective in HIV-1 Infection. PLoS Pathog. 2015, 11, e1005072. [CrossRef] [PubMed]

84. Dias, J.; Sobkowiak, M.J.; Sandberg, J.K.; Leeansyah, E. Human MAIT-cell responses toEscherichia coli: Activation, cytokine production, proliferation, and cytotoxicity. J. Leukoc. Biol. 2016, 100, 233-240. [CrossRef] [PubMed]

85. Booth, J.S.; Salerno-Goncalves, R.; Blanchard, T.G.; Patil, S.A.; Kader, H.; Safta, A.M.; Morningstar, L.M.; Czinn, S.J.; Greenwald, B.D.; Sztein, M.B. Mucosal-Associated Invariant T Cells in the Human Gastric Mucosa and Blood: Role in Helicobacter pylori Infection. Front. Immunol. 2015, 6, 466. [CrossRef] [PubMed]

86. Sharma, P.; Wong, E.B.; Napier, R.J.; Bishai, W.R.; Ndung'U, T.; Kasprowicz, V.O.; Lewinsohn, D.A.; Lewinsohn, D.; Gold, M.C. High expression of CD26 accurately identifies human bacteria-reactive MR1-restricted MAIT cells. Immunol. 2015, 145, 443-453. [CrossRef]

87. Wallington, J.C.; Williams, A.P.; Staples, K.J.; Wilkinson, T.M. IL-12 and IL-7 synergize to control mucosal-associated invariant T-cell cytotoxic responses to bacterial infection. J. Allergy Clin. Immunol. 2018, 141, 2182-2195.e6. [CrossRef] 
88. Medema, J.P.; Schuurhuis, D.H.; Rea, D.; Van Tongeren, J.; De Jong, J.; Bres, S.A.; Laban, S.; Toes, R.; Toebes, M.; Schumacher, T.; et al. Expression of the Serpin Serine Protease Inhibitor 6 Protects Dendritic Cells from Cytotoxic T Lymphocyte-Induced Apoptosis. J. Exp. Med. 2001, 194, 657-668. [CrossRef]

89. Wakao, H.; Sugimoto, C.; Kimura, S.; Wakao, R. Mucosal-Associated Invariant T Cells in Regenerative Medicine. Front. Immunol. 2017, 8, 8. [CrossRef]

90. Downey, A.M.; Kapłonek, P.; Seeberger, P.H. MAIT cells as attractive vaccine targets. FEBS Lett. 2019, 593, 1627-1640. [CrossRef]

91. Wang, H.; Kjer-Nielsen, L.; Shi, M.; D’Souza, C.; Pediongco, T.J.; Cao, H.; Kostenko, L.; Lim, X.Y.; Eckle, S.B.G.; Meehan, B.S.; et al. IL-23 costimulates antigen-specific MAIT cell activation and enables vaccination against bacterial infection. Sci. Immunol. 2019, 4. [CrossRef]

92. Howson, L.J.; Napolitani, G.; Shepherd, D.; Ghadbane, H.; Kurupati, P.; Preciado-Llanes, L.; Rei, M.; Dobinson, H.; Gibani, M.; Teng, K.W.W.; et al. MAIT cell clonal expansion and TCR repertoire shaping in human volunteers challenged with Salmonella Paratyphi A. Nat. Commun. 2018, 9, 253. [CrossRef] [PubMed]

93. Provine, N.M.; Amini, A.; Garner, L.C.; Spencer, A.J.; Dold, C.; Hutchings, C.; Reyes, L.S.; FitzPatrick, M.E.B.; Chinnakannan, S.; Oguti, B.; et al. MAIT cell activation augments adenovirus vector vaccine immunogenicity. Science 2021, 371, 521-526. [CrossRef] [PubMed] 